\title{
Oldest known cranium of a juvenile New World monkey (Early Miocene, Patagonia, Argentina): Implications for the taxonomy and the molar eruption pattern of early platyrrhines
}

\author{
Jonathan M.G. Perry ${ }^{\text {a, * }}$, Richard F. Kay ${ }^{\text {b }}$, Sergio F. Vizcaíno ${ }^{\text {c, d }}$, M. Susana Bargo c, e \\ a Center for Functional Anatomy and Evolution, The John Hopkins University, Baltimore, MD 21205, USA \\ b Department of Evolutionary Anthropology, Duke University, Durham, NC 27710, USA

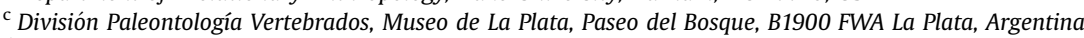 \\ d Consejo Nacional de Investigacione Científicas y Técnicas, Argentina \\ ${ }^{\text {e } C o m i s i o ́ n ~ d e ~ I n v e s t i g a c i o n e s ~ C i e n t i ́ f i c a s, ~ A r g e n t i n a ~}$
}

\section{A R T I C L E I N F O}

\section{Article history:}

Received 8 May 2013

Accepted 21 March 2014

Available online $\mathrm{xxx}$

\section{Keywords:}

Santa Cruz Formation

Homunculus

Killikaike

Platyrrhini

Primate tooth development

Diet

\begin{abstract}
A B S T R A C T
A juvenile cranium of Homunculus patagonicus Ameghino, 1891a from the late Early Miocene of Santa Cruz Province (Argentina) provides the first evidence of developing cranial anatomy for any fossil platyrrhine. The specimen preserves the rostral part of the cranium with deciduous and permanent alveoli and teeth. The dental eruption sequence in the new specimen and a reassessment of eruption patterns in living and fossil platyrrhines suggest that the ancestral platyrrhine pattern of tooth replacement was for the permanent incisors to erupt before $\mathrm{M}^{1}$, not an accelerated molar eruption (before the incisors) as recently proposed.

Two genera and species of Santacrucian monkeys are now generally recognized: $H$. patagonicus Ameghino, 1891a and Killikaike blakei Tejedor et al., 2006. Taxonomic allocation of Santacrucian monkeys to these species encounters two obstacles: 1 ) the (now lost) holotype and a recently proposed neotype of H. patagonicus are mandibles from different localities and different geologic members of the Santa Cruz Formation, separated by approximately 0.7 million years, whereas the holotype of $K$. blakei is a rostral part of a cranium without a mandible; 2) no Santacrucian monkey with associated cranium and mandible has ever been found. Bearing in mind these uncertainties, our examination of the new specimen as well as other cranial specimens of Santacrucian monkeys establishes the overall dental and cranial similarity between the holotype of Killikaike blakei, adult cranial material previously referred to H. patagonicus, and the new juvenile specimen. This leads us to conclude that Killikaike blakei is a junior subjective synonym of $H$. patagonicus.
\end{abstract}

() 2014 Elsevier Ltd. All rights reserved.

\section{Introduction}

Monkeys from the late Early Miocene Santa Cruz Formation (SCF) of the Austral Basin (Santacrucian South American Land Mammal Age; SALMA) achieved the southernmost biogeographical range recorded for any primate: $50-52^{\circ}$ south. This is about $2300 \mathrm{~km}$, or 20 degrees of latitude south of the present southern limit of living platyrrhines. All known monkey specimens of this age are found in the Santa Cruz Formation (e.g., Scott, 1928), although a fauna of similar aspect (but without primates) occurs in

\footnotetext{
* Corresponding author.

E-mail addresses: jperry31@jhmi.edu, ekgmowechashala@gmail.com (J.M.G. Perry).
}

other Argentinian provinces (e.g., San Juan Province) and in penecontemporaneous geological formations elsewhere in South America (e. g., Croft et al., 2003).

Cranial and postcranial specimens from a number of different localities in the SCF were ascribed to several platyrrhine taxa by Florentino Ameghino, who named Homunculus patagonicus in 1891 and many other primate genera and species. Since then, a number of additional primate specimens have been collected in SCF (Fleagle et al., 1988), including a partial cranium (Tauber, 1991). Ameghino's specimens, and most of the specimens collected since, are now allocated to a single taxon: $H$. patagonicus Ameghino, 1891a. Because the original holotype of $H$. patagonicus is lost, Tejedor and Rosenberger (2008) designated a neotype for this taxon. Slightly before that, another SCF primate taxon, Killikaike blakei Tejedor et al., 2006, was erected. This introduces certain practical 
difficulties: the neotype of $H$. patagonicus is a mandible but the holotype of $K$. blakei (and a single referred specimen) consists of upper teeth, a palate, and face. No specimen of either taxon preserves maxillary and mandibular parts of the same individual. Moreover, although several partial crania have been allocated to H. patagonicus (e.g., Rusconi, 1935; Hershkovitz, 1974; Tauber, 1991; Perry et al., 2010; Kay et al., 2012), each is damaged and distorted postmortem and none preserves a maxillary dentition in its unworn state, thus precluding detailed dental comparison.

In 2007, we found a juvenile cranial monkey specimen of H. patagonicus at Puesto Estancia La Costa (Perry et al., 2010; Kay et al., 2012). The new material preserves unworn upper molars and undistorted facial anatomy. It permits the first detailed comparison of unworn upper teeth of specimens assigned to $H$. patagonicus and $K$. blakei. To these comparisons are added comparisons of $K$. blakei with adult crania ascribed to $H$. patagonicus. In combination, the dental and cranial comparisons allow us to evaluate the taxonomic distinctness of the two taxa. Such an evaluation is of particular importance because of recent claims that one species (H. patagonicus) represents a basal member of the extant family Pitheciidae (Tejedor and Rosenberger, 2008), and that the other (K. blakei) is an early representative of the extant family Cebidae (Tejedor et al., 2006; Rosenberger, 2011).

\section{Materials and methods}

\section{Studied material}

The cranial specimen described here, MPM-PV 3505, was found at fossil level (Nivel Fossilifero) 5.3 of Tauber (1997) at S 51 ${ }^{\circ} 11^{\prime} 49.2^{\prime \prime}$, W $069^{\circ} 05^{\prime} 10.1^{\prime \prime}$ in the intertidal zone at Puesto Estancia La Costa (PLC). At the time of discovery, the palate was exposed and the teeth were clearly visible (Fig. 1).

MPM-PV 3505 was illustrated and briefly discussed previously (Perry et al., 2008; Kay et al., 2012). We describe it in detail below. Among the more important specimens mentioned in the descriptions below are: 1) A facial fragment (MACN-A 5968) from PLC described by Ameghino (1904a,b), and more fully by Bluntschli (1931); 2) A partial cranium, CORD-PZ 1130 from PLC (Tauber, 1991); 3) specimens assigned to K. blakei (MPM-PV 5000 and 1607); 4) several specimens collected since 2004 that have not yet been fully described, especially including a cranium from Killik Aike Norte (KAN): MPM-PV 3502 (Fig. 2).

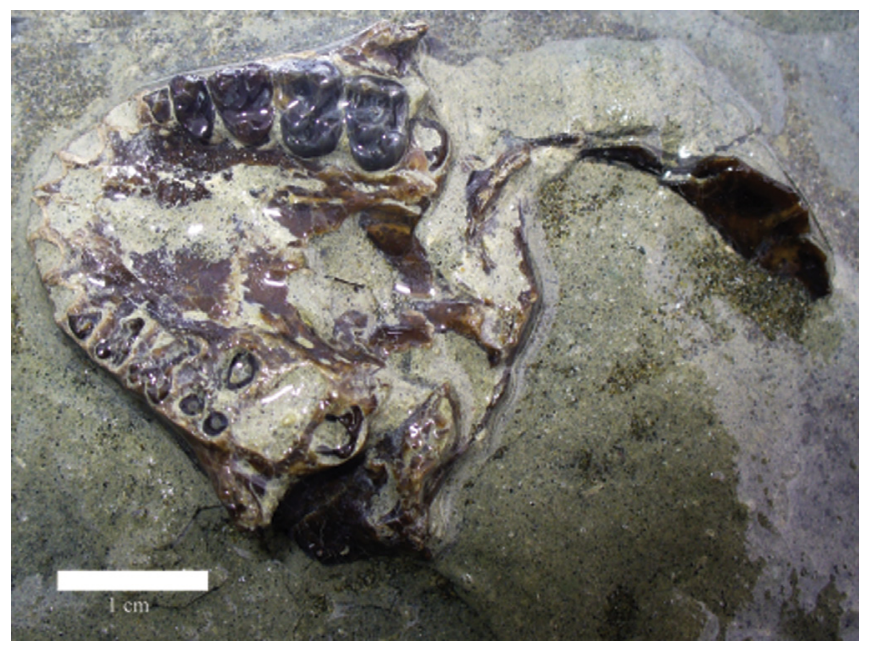

Figure 1. MPM-PV 3505 in situ at the time of discovery. Scale bar $=1 \mathrm{~cm}$.

\section{Methods}

When discussing the identity of MPM-PV 3505, we present dental measurements of several other primate specimens listed in Table 1. The description of MPM-PV 3505 is based on visual examination of the specimen and analysis of micro-CT scans. The specimen was scanned at the University of Texas High-Resolution X-ray CT Facility with an inter-slice spacing of $0.03928 \mathrm{~mm}$ resulting in 970 slices. Scans were examined and threedimensional reconstructions composed in Avizo 7.0 (Visualization Sciences Group, 2012) and VGStudio Max 1.2 (Volume Graphics, Heidelberg, Germany).

To evaluate the likelihood that the Santacrucian primate upper molars represent a single species, we undertook detailed morphological comparisons of the face and teeth. Also, we compared metric variation in $\mathrm{M}^{1}$ and $\mathrm{M}^{2}$ length and breadth in the fossil sample with variation in the same dimensions in a single subspecies of extant atelid platyrrhine, Ateles geoffroyi vellerosus. We also combined $\mathrm{M}^{1}$ and $\mathrm{M}^{2}$ dimensions in this sample in a principal components analysis.

\section{Acronyms}

CORD-PZ, Museo de Paleontología, Universidad Nacional de Córdoba, Córdoba, Argentina. MACN, Museo Argentino de Ciencias Naturales 'Bernardino Rivadavia', Buenos Aires, Argentina. MACNA, Museo Argentino de Ciencias Naturales 'Bernardino Rivadavia', Colección Nacional Ameghino, Buenos Aires, Argentina. MLP, Museo de La Plata, La Plata, Argentina. MNHN-Bol-V, Museo Nacional de Historia Natural, La Paz, Bolivia. MPM-PV, Museo Regional Provincial Padre Manuel Jesús Molina, Río Gallegos, Argentina. Upper and lower teeth are identified by a super- and subscript and deciduous teeth are indicated by a ' $\mathrm{d}$ ', viz, $\mathrm{dP}^{3}$ for the upper deciduous third premolar.

\section{Systematic paleontology}

Order Primates Linnaeus, 1758

Infraorder Platyrrhini É. Geoffroy Saint-Hilaire, 1812

Family incertae sedis

Genus Homunculus patagonicus Ameghino, 1891a

H. patagonicus Ameghino, 1891a

\section{Synonyms}

Synonyms of $H$. patagonicus are: Ecphantodon ceboides Mercerat, 1891; Anthropops perfectus Ameghino, 1891b; Stilotherium grandis Ameghino, 1894; Homunculus ameghini Bluntschli, 1931; K. blakei Tejedor et al., 2006.

\section{Holotype and neotype}

MACN-A 634 is a right hemimandible with the root of $\mathrm{I}_{1}$, broken $\mathrm{I}_{2}, \mathrm{C}, \mathrm{P}_{2}-\mathrm{P}_{4}$, broken $\mathrm{M}_{1}$, and root of $\mathrm{M}_{2}$. It also includes part of the symphyseal region. The original specimen is lost but there is a cast at the MACN, dental measurements and figures in Rusconi (1934), measurements, and a detailed description in Bluntschli (1931). A neotype was erected by Tejedor and Rosenberger (2008) and is MACN-A 5757, a mandible.

\section{Described material}

The described material is a cranium, MPM-PV 3505, housed at the Museo Regional Provincial Padre Manuel Jesús Molina, Río 


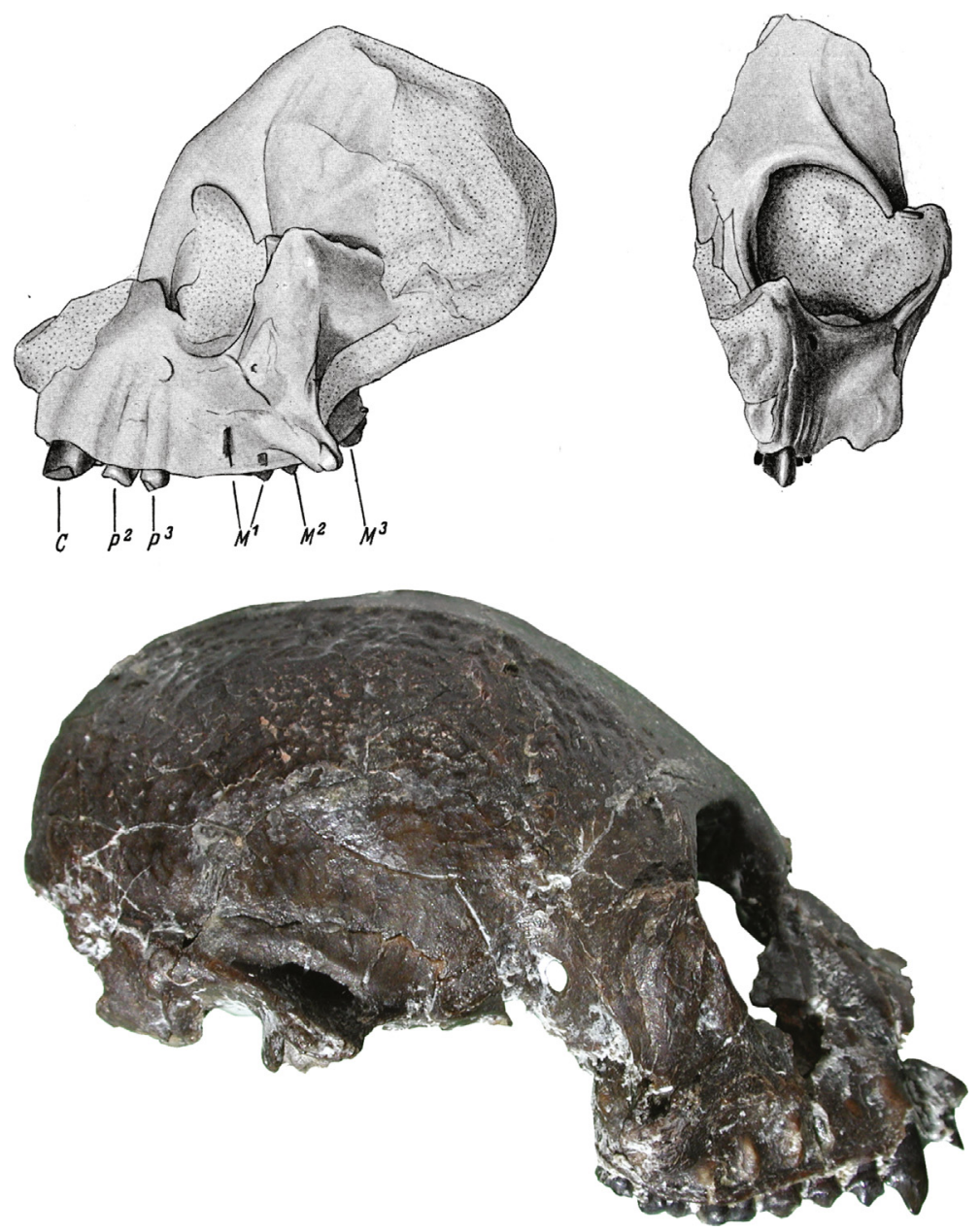

Figure 2. Major cranial material previously referred to Homunculus patagonicus: drawings at top, MACN-A 5968 (after Bluntschli, 1931 ); photograph at bottom, CORD-PZ 1130.

Gallegos, Argentina. A list of primate specimens from the Santa Cruz Formation (published and unpublished, through 2011) is provided in Appendix 16.1 in Kay et al. (2012).

\section{Other referred material}

All material previously described as $K$. blakei is included in H. patagonicus, namely MPM-PV 5000 (a rostral part of a cranium from Killik Aike Norte) and MPM-PV 1607 (a right maxilla with upper premolars and molars from the same locality).

\section{Type locality}

The holotype of $H$. patagonicus (MACN-A 634) was collected by Carlos Ameghino from the north shore of the estuary of the Rio Gallegos (Bluntschli, 1931). The neotype (MACN-A 5757) was collected, also by Carlos Ameghino, from Corriguen Aike, now called Puesto Estancia La Costa (Tejedor and Rosenberger, 2008).

\section{Distribution}

Material here assigned to $H$. patagonicus is from several Atlantic coastal and some inland localities of the Santa Cruz Formation, Santa Cruz Province, Argentina (Fig. 3). Subdivisions of the Santa Cruz Formation are those proposed by Tauber (1994). The primary localities are Killik Aike Norte (KAN), Estancia La Costa (ELC), Puesto Estancia La Costa (PLC), and Cerro Observatorio (equivalent to
Monte Observación of the old literature). Specimens from ELC and PLC are of similar age ( $17.5 \mathrm{Ma})$ and are from the lower geologic member (or Estancia La Costa Member) of SCF; those from KAN are younger ( 16.8 Ma) and are from the overlying Estancia Angelina Member (Fleagle et al., 2012; Perkins et al., 2012). Most specimens from Cerro Observatorio for which the stratigraphic positions are established are from the Estancia La Costa Member and are similar in age to PLC.

\section{Description of the new specimen}

Cranium Most of the facial skeleton of MPM-PV 3505 is preserved including the orbits, the nasal cavity, alveolar processes, the anterior roots of the zygomatic arches, and a small part of the forehead and anterior cranial fossa (Fig. 4). A small fragment of the left side of the braincase was connected to the rest of the specimen via matrix at the time of discovery, but is now a separate piece. The posterior part of the cranium is broken away anterior to the glenoid fossae and posterior to the lesser wings of the sphenoid. The pterygoid plates are missing and the floor of the right orbit is broken away postero-inferiorly. A crack running horizontally through the specimen midway through both orbits caused a slight offset and damaged the interorbital region, but otherwise the specimen is undistorted

Alveoli are preserved for the permanent upper incisors but these sockets are in-filled with consolidated sediment. The alveoli show that those teeth were fully erupted and likely fell out 
Table 1

Primate specimens mentioned in the text or figures, Santa Cruz Formation, Santa Cruz Province, Argentina.

\begin{tabular}{|c|c|c|}
\hline Specimen & Element & Locality \\
\hline CORD-PZ 1130 & $\begin{array}{l}\text { Cranial fragment that preserves } \\
\text { most of the left side including } \\
\text { the face (Tauber, 1991) }\end{array}$ & $\begin{array}{l}\text { Puesto Estancia } \\
\text { La Costa }\end{array}$ \\
\hline MACN-A 634 & $\begin{array}{l}\text { Holotype of Homunculus } \\
\text { patagonicus, a mandible (now } \\
\text { lost) }\end{array}$ & $\begin{array}{l}\text { North bank of the } \\
\text { Rio Gallegos estuary }\end{array}$ \\
\hline MACN-A 5757 & $\begin{array}{l}\text { Nearly complete lower right } \\
\text { hemimandible with associated } \\
\text { parts of the left hemimandible, } \\
\text { neotype for Homunculus } \\
\text { patagonicus (Tejedor and } \\
\text { Rosenberger, 2008) }\end{array}$ & $\begin{array}{l}\text { Puesto Estancia } \\
\text { La Costa }\end{array}$ \\
\hline MACN-A 5968 & $\begin{array}{l}\text { Cranial fragment (face) } \\
\text { (Ameghino, 1894; Bluntschli, } \\
\text { 1931; Rusconi, 1935; Tauber, } \\
\text { 1991) }\end{array}$ & $\begin{array}{l}\text { Puesto Estancia } \\
\text { La Costa }\end{array}$ \\
\hline MACN SC-334 & Right $\mathrm{M}^{1}$ or $\mathrm{M}^{2}$ & Cerro Observatorio \\
\hline MPM-PV 3501 & $\begin{array}{l}\text { Slightly distorted, nearly } \\
\text { complete cranium }\end{array}$ & Puesto Estancia La Costa \\
\hline MPM-PV 3502 & $\begin{array}{l}\text { Undistorted cranium } \\
\text { preserving all but the } \\
\text { dorsolateral part of the } \\
\text { braincase on the left side } \\
\text { (undescribed specimen) }\end{array}$ & $\begin{array}{l}\text { Killik Aike Norte } \\
\text { (north shore of the } \\
\text { Rio Gallegos estuary) }\end{array}$ \\
\hline MPM-PV 3503 & $\begin{array}{l}\text { Left half of a cranium notable } \\
\text { for preserving a nearly unworn } \\
\text { postcanine dentition } \\
\text { (undescribed specimen) }\end{array}$ & $\begin{array}{l}\text { Puesto Estancia } \\
\text { La Costa }\end{array}$ \\
\hline MPM-PV 3505 & $\begin{array}{l}\text { Cranial fragment of a juvenile } \\
\text { individual that preserves much } \\
\text { of the face, several teeth and } \\
\text { tooth roots, and the anterior } \\
\text { aspect of the braincase }\end{array}$ & $\begin{array}{l}\text { Puesto Estancia La Costa } \\
\text { (FL } 5.3 \text { (Tauber, 1994) } \\
\text { at S51 } 11^{\prime} 49.2^{\prime \prime}, \\
\text { W069 } 05^{\prime} 10.1^{\prime \prime} \text { ) }\end{array}$ \\
\hline MPM-PV 5000 & $\begin{array}{l}\text { Cranial fragment preserving the } \\
\text { face, several teeth, and the } \\
\text { anterior aspect of the braincase } \\
\text { along with a maxilla. Holotype } \\
\text { of Killikaike blakei Tejedor et al., } \\
2006 \text {. }\end{array}$ & $\begin{array}{l}\text { Killik Aike Norte } \\
\text { (north shore of the } \\
\text { Rio Gallegos estuary) }\end{array}$ \\
\hline MPM-PV 1607 & $\begin{array}{l}\text { Maxilla with cheek teeth, } \\
\text { hypodigm of Killikaike blakei }\end{array}$ & Killik Aike Norte \\
\hline
\end{tabular}

For other Santa Cruz primate specimens, see Kay et al. (2012).

postmortem. Based on the size of the alveoli, the upper central incisor was slightly larger than the lateral. The crowns of the right $\mathrm{dP}^{2}-\mathrm{dP}^{4}$ and $\mathrm{M}^{1}$ are broken away and likely were lost to erosion by wave action in the days before discovery. The right $\mathrm{M}^{2}$ is missing and its alveolus was in-filled with loose sediment, so it likely fell out postmortem.

As with CORD-PZ 1130 and MPM-PV 5000, the premaxillae are very short and comprise the floor and extreme rostral edge of the nasal aperture.

The nasals extend superiorly to suture with the frontal at a point midway along the orbital margin and dorsal to the lacrimal fossa and canal. Though broken rostrally, the nasals are long and narrow (reconstructed to $10.70 \mathrm{~mm} \times 3.20 \mathrm{~mm}$ each) and the interorbital region is narrow (interorbital breadth is $3.53 \mathrm{~mm}$ ), as is also the case for CORD-PZ 1130 (5.20 mm), MACN-A 5968 (5.30 mm), and MPM-PV 5000 (4.40 mm).

The lacrimal fossa receives contributions from the maxillary bone rostrally and from the lacrimal bone caudally. As the lacrimal fossa is completed anteriorly by the maxilla, the lacrimal bone remains within the orbit. An interorbital process of the maxilla is interposed between the lacrimal and nasal bones and makes sutural contact with the frontal, thereby excluding the lacrimal from contacting the nasal. This pattern contrasts with that of CORD-PZ 1130 where the lacrimal extends onto the face to contact the nasal (RFK, Personal observations). These bones are fused and sutures obliterated in MACN-A 5968 (Bluntschli, 1931). The condition observed in CORD-PZ 1130 also is observed on the right side of the cranium of MPM-PV 5000. Variation in this feature occurs in some extant platyrrhines, for example Alouatta (RFK, Personal observations).

The maxilla is interposed between the zygomatic and lacrimal bones on the ventral orbital margin. The remainder of the orbital margin is composed of the frontal medially and dorsally; and the zygomatic dorsally, dorsolaterally, and ventrolaterally. Although slightly distorted, the outline of the orbit is roughly circular (mediolateral dimension $=12.3 \mathrm{~mm}$, dorsoventral dimension $=12.8 \mathrm{~mm}$ ). This is also the case for MPM-PV 5000 and MPM-PV 3502 (Table 2).

As viewed in the dorsal aspect, orbital convergence resembles that of callitrichine platyrrhines, which have less convergence than extant non-callitrichine platyrrhines (Ross, 1995). This callitrichinelike orbital orientation in MPM-PV 3505 occurs in Tremacebus harringtoni Rusconi, 1933, in Dolichocebus gaimanensis Kraglievich, 1951, and in other Homunculus (CORD-PZ 1130, and MPM-PV 5000) (see Hershkovitz, 1974; Kay et al., 2008, 2012).

Postorbital closure is nearly complete but for a small lateral orbital fissure (Figure 14 in Hershkovitz, 1974) and an inferior orbital fissure that does not extend as far laterally as it does in Aotus. The lateral orbital fissure is practically round, as in CORD-PZ 1130 and MPM-PV 3502 (not preserved in MPM-PV 5000). On MPM-PV 3505, one cannot say what was the arrangement of contacts among the zygomatic, parietal, frontal, and alisphenoid bones at pterion. In CORD-PZ 1130, there is a relatively broad contact between the frontal bone and the alisphenoid at pterion. This is ubiquitous in catarrhines and a common variant in Alouatta (Ashley-Montague, 1933). This feature is not mentioned by Tauber (1991) but was observed on the specimen by RFK. In other specimens of Homunculus, (e.g., MPM-PV 5000, MPM-PV 3502) the bones at pterion are either fused or broken away.

The optic canal is visible bilaterally from the interior of the skull and on CT images with the matrix digitally removed. Its mediolateral dimension is $2.3 \mathrm{~mm}$. The dorsoventral dimension cannot be measured reliably because its ventral margin is damaged.

The frontal is well preserved rostrally but broken caudally. A slight depression occurs caudally and superiorly to glabella. The same morphology is visible in CORD-PZ 1130, MACN-A 5968, MPMPV 3502, and MPM-PV 5000. Glabella itself is not prow-like as often described in extant platyrrhines (e.g., in callitrichines, Hershkovitz, 1981; Fig. IV.81, pp. 198) the brow ridges are weak and become indistinct laterally, but are slightly raised medially. Even at this early stage in facial development, there is no vestige of the metopic suture, which would have separated the right and left frontal bones at an earlier stage of ontogeny. The angle of the forehead relative to the Frankfort horizontal plane cannot be determined from the specimen.

The olfactory fossa is small and anteriorly projecting (Fig. 5), as described for Dolichocebus (Kay and Fleagle, 2010, Fig. 1.), CORD-PZ 1130 (Tauber, 1991, Fig. 6.), and MPM-PV 3502 (Kay et al., 2012, Fig. 16.4.).

The nasal cavity and paranasal sinuses are preserved with some breakage and distortion. The specimen possesses a large maxillary sinus, as in CORD-PZ 1130, MPM-PV 3502, and most platyrrhines (Personal observations and Kay et al., 2006; Rossie, 2006). The inferior nasal concha is preserved, as are a vertically disposed lacrimal canal (Rossie and Smith, 2007) and its opening into the nasal cavity. The frontal sinus is absent in MPM-PV 3505. Cancellous bone is present between the inner and outer table of bone in the frontal but does not represent air cells and is not connected to the nasal cavity. This condition is variable in the SCF sample: CORD- 


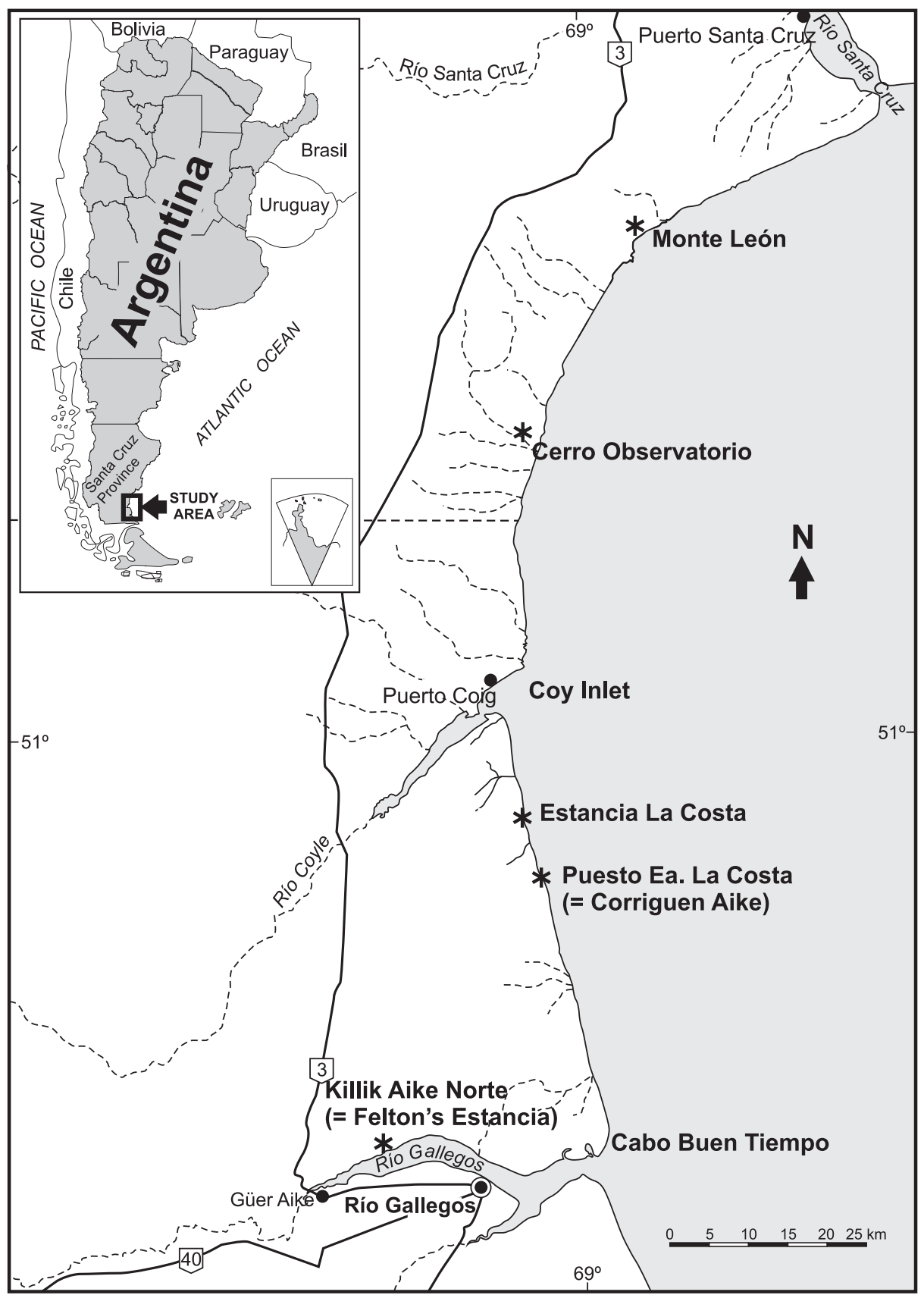

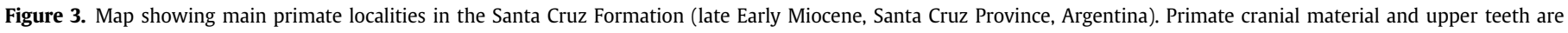
recorded at Estancia Killik Aike Norte (formerly Felton's Estancia), Puesto Estancia La Costa (formerly Corriguen Aike), and Cerro Observatorio.

PZ 1130 has a frontal sinus but MPM-PV 3502 does not (RFK, Personal observations). A small cupular (sphenoid) recess is visible but a sphenoid sinus sensu Rossie (2006) is not evident, nor is one present in MPM-PV 3502 (Fig. 6).

A narrow alveolar diastema separates the lateral incisor alveolus from the deciduous canine alveolus, as in CORD-PZ 1130 and MPMPV 5000. The alveolar process of the maxilla is deep for a platyrrhine at this stage of dental development (facial height is $8.06 \mathrm{~mm}$; see Table 2). The singular infraorbital foramen of the maxilla is very small and positioned dorsal to $\mathrm{dP}^{3}$.

The zygomatic bone makes a broad, diagonal contact with the maxilla beneath the orbit. As in all anthropoids, on the ventral orbital margin the zygomatic bone is separated from the lacrimal bone by a process of the maxilla. In Malagasy strepsirrhines, the zygomatic contacts the lacrimal on the ventral orbital margin (Cartmill, 1978). The zygomatico-facial foramen is very small and singular, as it is in MPM-PV 3702 and MPM-PV 5000. A collection of three very small foramina is present in CORD-PZ 1130. The root of the zygomatic arch is raised above the tooth row; it is robust in the dorsoventral plane, especially for an immature specimen.

A portion of the anterior cranial fossa is preserved (Figs. 4D and 5 ), within which the suture between the frontal and sphenoid is clearly visible. The lesser wing of the sphenoid is perfectly preserved and the left anterior clinoid process is intact. The cribriform plate of the ethmoid is visible in superior view; there is no crista galli. 
A
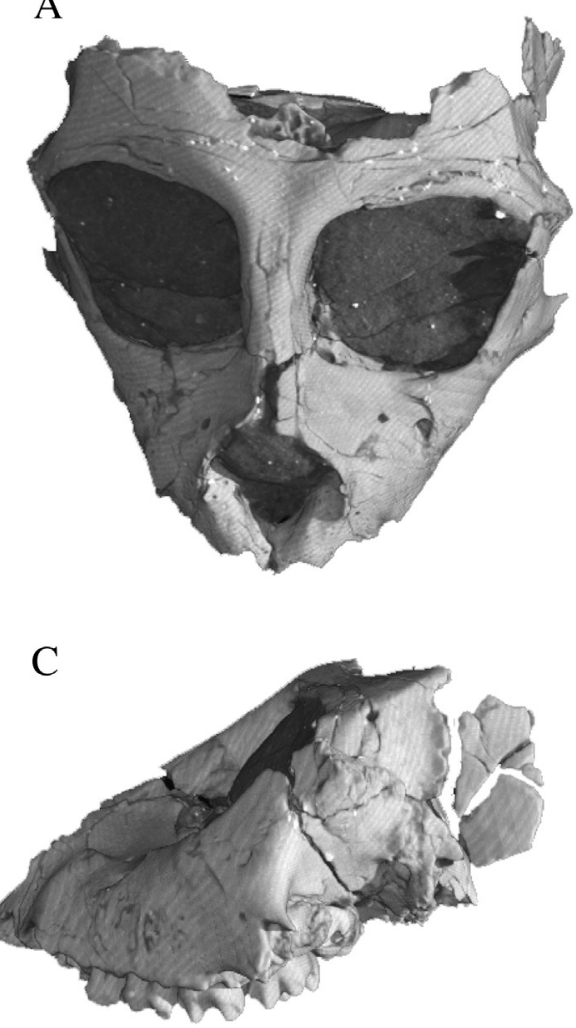

$\mathrm{B}$

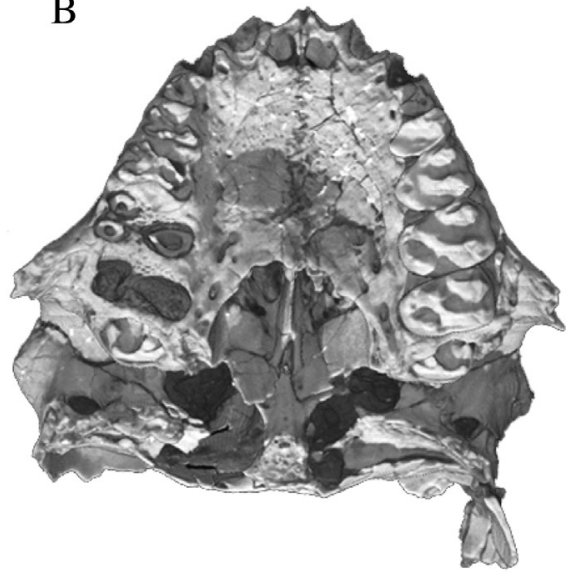

$\mathrm{D}$

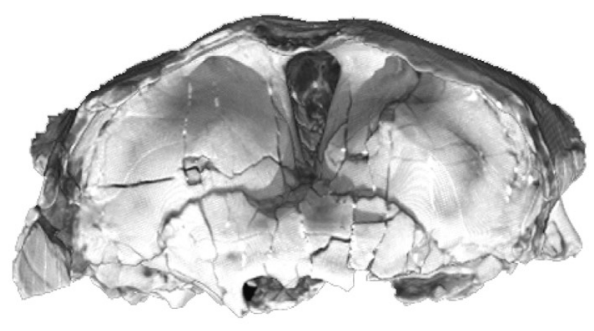

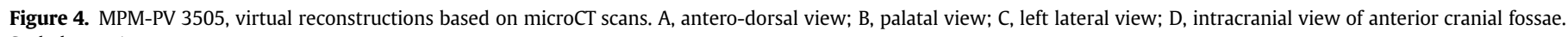
Scale bar $=1 \mathrm{~cm}$.

The palate is intact, with rounded incisive foramina (left: $1.68 \mathrm{~mm}$ mediolaterally by $1.88 \mathrm{~mm}$ anteroposteriorly). The palatal process of the palatine has a weak medial spine, weaker than in MPM-PV 5000, but resembles the latter in other palatal features. The caudal margin of the palatine bone thins out at the posterior nasal aperture, is invaginated, and ends at the midline opposite the middle of $\mathrm{M}^{1}$ (these features are not preserved on CORD-PZ 1130). The root of the pterygoid plates is preserved on the left side; it is positioned very far laterally, as also seen in CORD-PZ 1130 and MPM-PV 5000.

The vomer is well-preserved and visible from the palatal view. The basisphenoid is complete caudally and its suture with the basioccipital is unfused.

Dentition As already noted, alveoli are visible for similar sized right and left permanent incisors (the $\mathrm{I}^{1}$ root socket is slightly larger than that of $\mathrm{I}^{2}$ ). Alveoli for both deciduous canines also are present (Fig. 4B). Both permanent canines are present, but unerupted. The alveoli of the permanent incisors and deciduous canines are separated by short alveolar diastemata

The left $\mathrm{dP}^{2}-\mathrm{dP}^{4}$ are fully erupted. The crowns of the right $\mathrm{dP}^{2}-\mathrm{dP}^{4}$ are broken away at the cemento-enamel junction, but the roots are intact. The left $\mathrm{M}^{1}$ and $\mathrm{M}^{2}$ are fully erupted. The crown of the right M1 is broken away at the cemento-enamel junction, but the roots are intact. The entire right $\mathrm{M}^{2}$ is missing (including the roots). The left and right $\mathrm{M}^{3}$ crowns are preserved unerupted and partially exposed in their bony crypts. The left $\mathrm{dP}^{2}$ is badly damaged; the left $\mathrm{dP}^{3}-\mathrm{dP}^{4}$ are heavily worn.

As visualized in CT scans (Fig. 7), the crowns for the unerupted right and left permanent canines and three permanent premolars
$\left(\mathrm{P}^{2}-\mathrm{P}^{4}\right)$ are present. They are at the bell stage of development, with fully formed crowns but lacking roots.

Bilaterally, a single buccal root for $\mathrm{dP}^{2}$ is preserved. A lingual root probably was present but was reabsorbed near the crown of its permanent replacement tooth. Its crown is broken and all that can be discerned is that it had a wide, flat basin distolingually. The $\mathrm{dP}^{3}$ has two widely separate buccal roots and a single lingual root. The $\mathrm{dP}^{3}$ crown has a paracone buccally that supports pre- and postparacristae, but there is no metacone. Mesial to the paracone there is a small parastyle. Occlusal details of the lingual aspect of $\mathrm{dP}^{3}$ are obscured by wear but the transversely oval shape of the tooth suggests that there was a protocone. The worn three-rooted $\mathrm{dP}^{4}$ is highly molarized with a paracone and metacone buccally and a protocone and a strong hypocone lingually.

The shapes of the permanent upper canine and premolars can be visualized with CT imagery (Fig. 8). The canine's crown appears to be nearly fully formed but its root is not yet formed. The crown has a strong lingual ridge running from the apex to the base of the crown. This ridge separates a deep groove mesially from a shallow groove distally. The tooth also bears a small distal heel. The permanent premolars are less molarized than the deciduous ones and have triangular occlusal outlines. The paracone is tall in $\mathrm{P}^{2}$ and a small protocone is present lingually. The postparacrista is short and there is no hypocone. The $\mathrm{P}^{3}$ and $\mathrm{P}^{4}$ are similar by each having a cristiform paracone, and well-developed protocone and also a hypocone, the latter disposed on a distal marginal cingulum.

The first and second upper molars (Fig. 9) are four-cusped. On $\mathrm{M}^{1}$ the metacone is nearly as large as the paracone; on $\mathrm{M}^{2}$ the metacone is much smaller than the paracone. On both teeth, the metacone and paracone are widely separated leaving the 
Table 2

General cranial measurements ${ }^{\mathrm{a}}$ for the best-preserved Santa Cruz specimens.

\begin{tabular}{|c|c|c|c|c|c|c|c|}
\hline Specimen & Palate length $^{\mathrm{b}}$ & Palate breadth ${ }^{c}$ & Orbit height $^{\mathrm{d}}$ & Orbit width $^{\mathrm{d}}$ & Interorbital breadth $^{\mathrm{e}}$ & Facial height $^{\mathrm{f}}$ & Cranial breadth $^{g}$ \\
\hline $\begin{array}{l}\text { MPM-PV } 3505 \text { (juvenile } \\
\quad \text { cranium -FN PLC-JP-07-12) }\end{array}$ & 24.99 & 23.24 & 12.75 & 12.16 & 3.53 & 8.06 & 27.70 \\
\hline MPM-PV 5000 & 25.80 & 22.74 & 14.01 & 12.23 & 4.40 & 9.48 & 27.80 \\
\hline MPM-PV 3503 (FN RK-04-43) & $23.36^{*}$ & 23.12 & 16.60 & $9.78^{*}$ & $5.52^{*}$ & 11.15 & $28.28^{*}$ \\
\hline MPM-PV 3502 (FN KAN-CL-04-1) & 28.44 & 24.23 & 14.66 & 13.45 & 4.20 & 10.82 & $25.28^{*}$ \\
\hline MPM-PV 3501 (FN PLC-JP-04-58) & $25.46^{*}$ & 22.96 & 14.85 & 14.30 & 5.06 & 11.71 & 24.39 \\
\hline
\end{tabular}

${ }^{\text {a }}$ All measurements are in millimeters; those identified with an asterisk are estimates as the anatomy is poorly preserved or distorted in that region of that specimen. Field numbers (FN) are indicated when available.

b Distal edge of $\mathrm{M}^{3}$ to inferior nasal spine.

c Buccal edge of $\mathrm{RM}^{1}$ to buccal edge of $\mathrm{LM}^{1}$.

d Greatest dimension.

e Narrowest dimension.

${ }^{\mathrm{f}}$ Inferior orbital rim to inferior edge of alveolar bone at the level of the posterior edge of $\mathrm{P}^{4}$; vertical distance.

g At postorbital constriction.

postparacrista and premetacrista much longer than the preparacrista and postmetacritsta. All four buccal crests are aligned mesiodistally. Neither a parastyle nor a metastyle is present on $\mathrm{M}^{1}$. The $\mathrm{M}^{2}$ has a parastyle but no metastyle. The $\mathrm{M}^{1}$ and $\mathrm{M}^{2}$ have small paraconules supporting distinct cristae. The preparaconule crista is continuous with the preprotocrista at the mesial margin of the tooth, which otherwise lacks a mesial cingulum. The postparaconule crista runs directly buccally and is continuous with the anterior transverse crista arising from the paracone. There is no metaconule. Arising from the protocone is a strong preprotocrista that joins the preparaconule crista. The postprotocrista runs diagonally towards the base of the metacone, where it reaches a sharply delineated posterior transverse crista of the metacone. The postprotocrista on $\mathrm{M}^{1}$ is directed towards the base of the metacone. This crest lacks a distal spur directed towards the hypocone (this postprotocrista spur is absent on $\mathrm{dP}^{4}$ also). Early Miocene Soriacebus and Mazzonicebus have a spur whereas Dolichocebus and Carlocebus do not (Kay, 2010). The hypocone is large, distal, and slightly lingual to the protocone on both teeth. There is a prominent prehypocrista that directly connects with the wall of the postprotocrista, closing off the talon lingually. The posthypocrista is strong and confluent with a distal cingulum.

There is, at most, a weak buccal cingulum on $\mathrm{M}^{1}$ or $\mathrm{M}^{2}$. A welldeveloped lingual cingulum runs lingually from the apex of the hypocone around the base of the protocone, delineating a wide

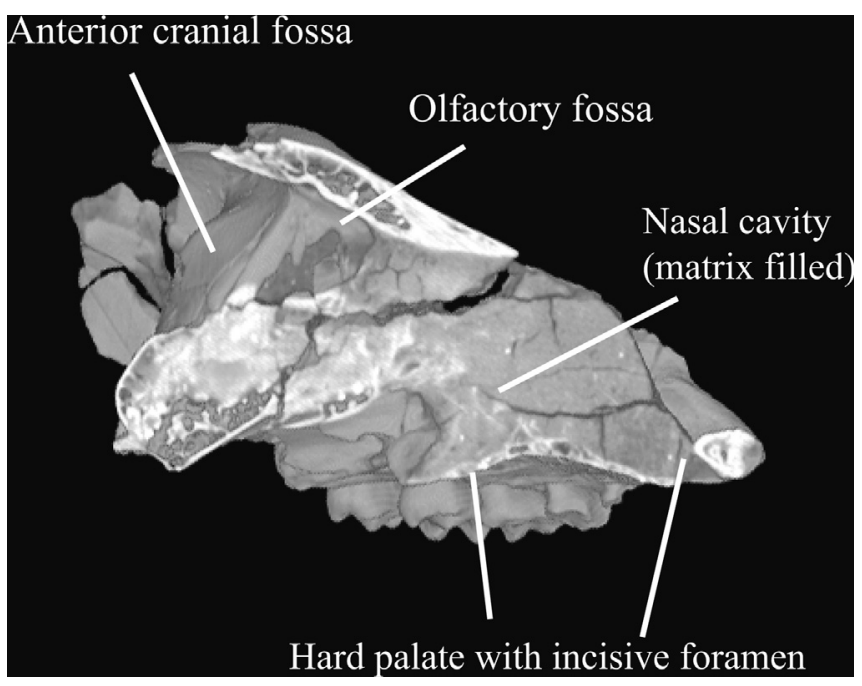

Figure 5. Coronal section of MPM-PV 3505 showing the olfactory fossa projecting anterior to the anterior cranial fossa. See also Fig. 4D. cingulum shelf before joining the lingual aspect of the protocone; there it reaches the preprotocrista. The lingual cingulum is unadorned by a pericone or other cusp.

The $\mathrm{M}^{2}$ is slightly smaller than $\mathrm{M}^{1}$, especially in its mesiodistal dimension. The $\mathrm{M}^{1}$ has two buccal roots and one lingual root. The roots of $\mathrm{M}^{1}$ are fully formed whereas those of $\mathrm{M}^{2}$ are still widely open at the apices (Fig. 10). The $\mathrm{M}^{2}$ has a single buccal root and one lingual root. The buccal root is bilobate in cross section and has a single pulp cavity. Because the $\mathrm{M}^{2}$ root apex remains open, the buccal root could alternatively be considered to have two separate roots that are joined near the cervix (see also Fig. 8).

The $\mathrm{M}^{3}$ has a rectangular occlusal outline, wider (buccolingually) than it is long. It lacks a hypocone, but there is a deep groove between the protocone and the strong (deeply incised and wide) lingual cingulum. The metacone is small and the paracone is very tall. A small cuspule (perhaps a metaconule) is present on the

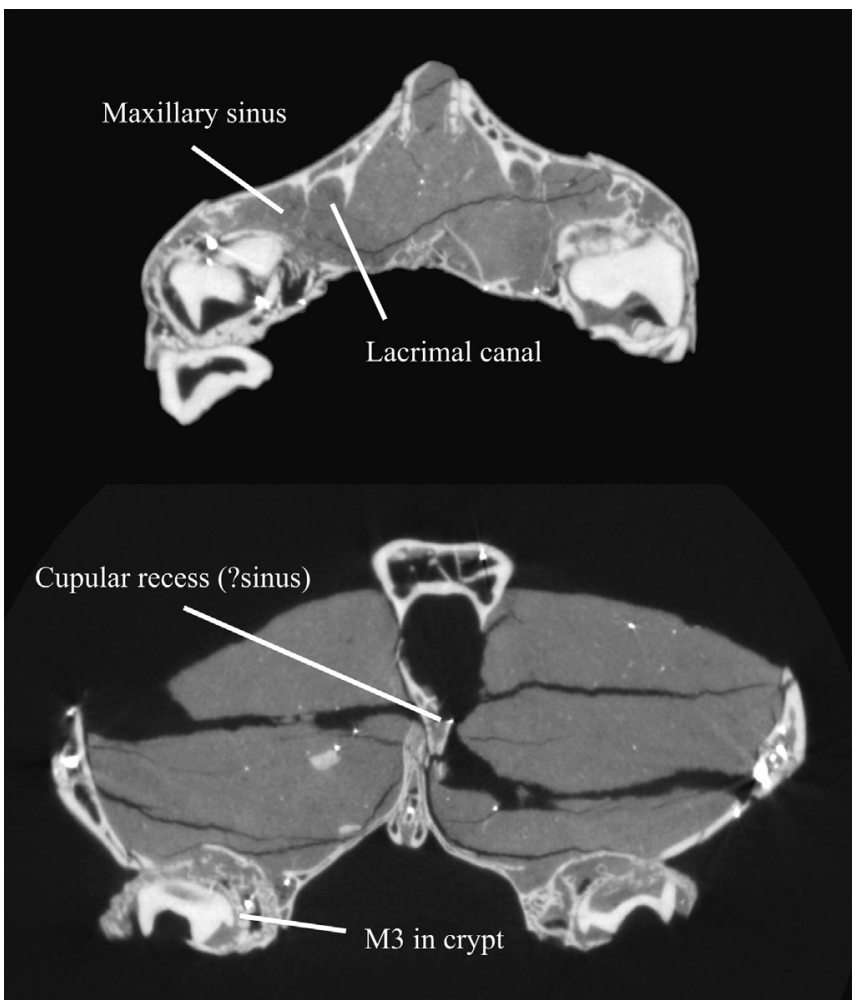

Figure 6. Coronal sections of MPM-PV 3505 showing maxillary sinus (upper image), cupular recess (lower image), and the $\mathrm{M}^{3}$ lacking roots (both images). 


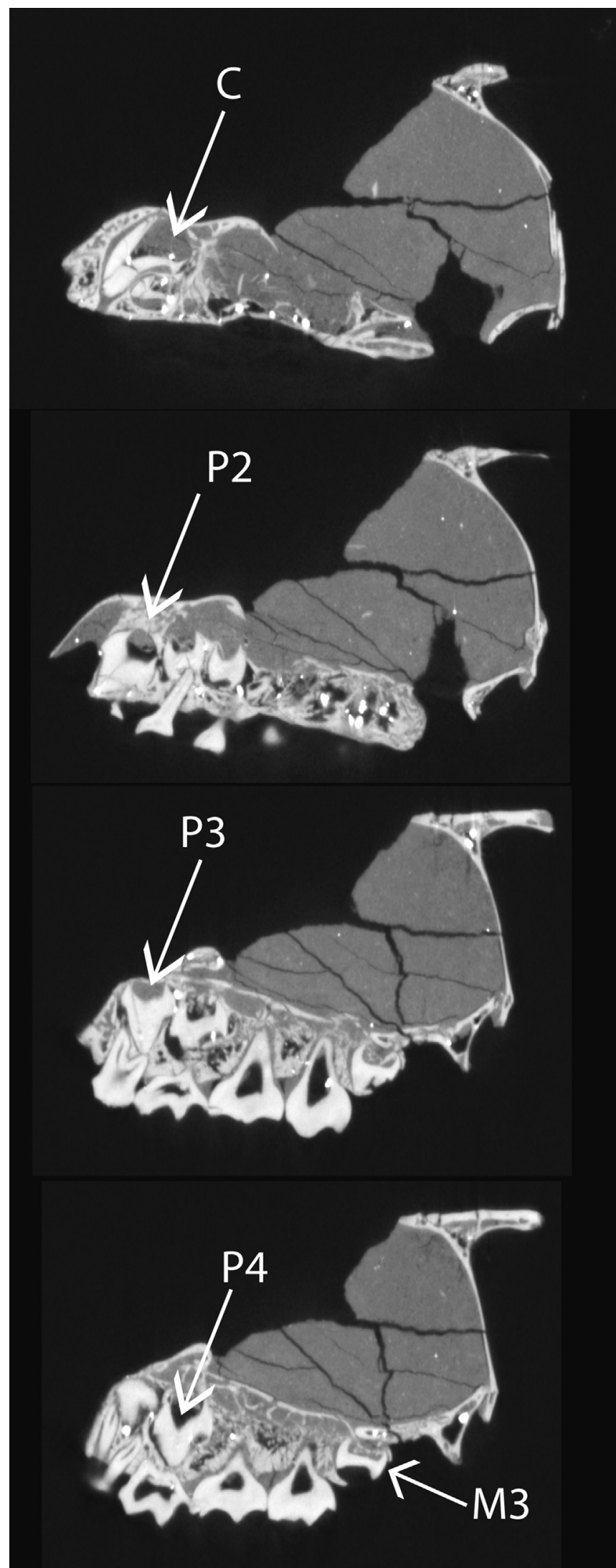

Figure 7. Four parasagittal CT scans of MPM-PV 3505 showing the $\mathrm{C}-\mathrm{P}^{4}$ in crypts. postprotocrista on the left $\mathrm{M}^{3}$ but absent on the right. The roots of $\mathrm{M}^{3}$ are undeveloped (Fig. 6).

\section{Results}

\section{Dental eruption sequence}

MPM-PV 3505 provides evidence of the dental eruption sequence. Alveoli for the permanent incisors are present. These teeth had already erupted and, given that the alveoli were filled with matrix, likely were lost shortly after death. The crown for the permanent canine is fully developed within its crypt, but its root is not yet fully formed. This tooth is positioned above and distal to the vacant alveolus of the deciduous canine. The latter would have been in occlusion at the time of death (Fig. 7). The $\mathrm{M}^{3}$ is at a similar stage of development as the permanent canine: unerupted in its crypt with a complete crown and unformed root (Fig. 6). The

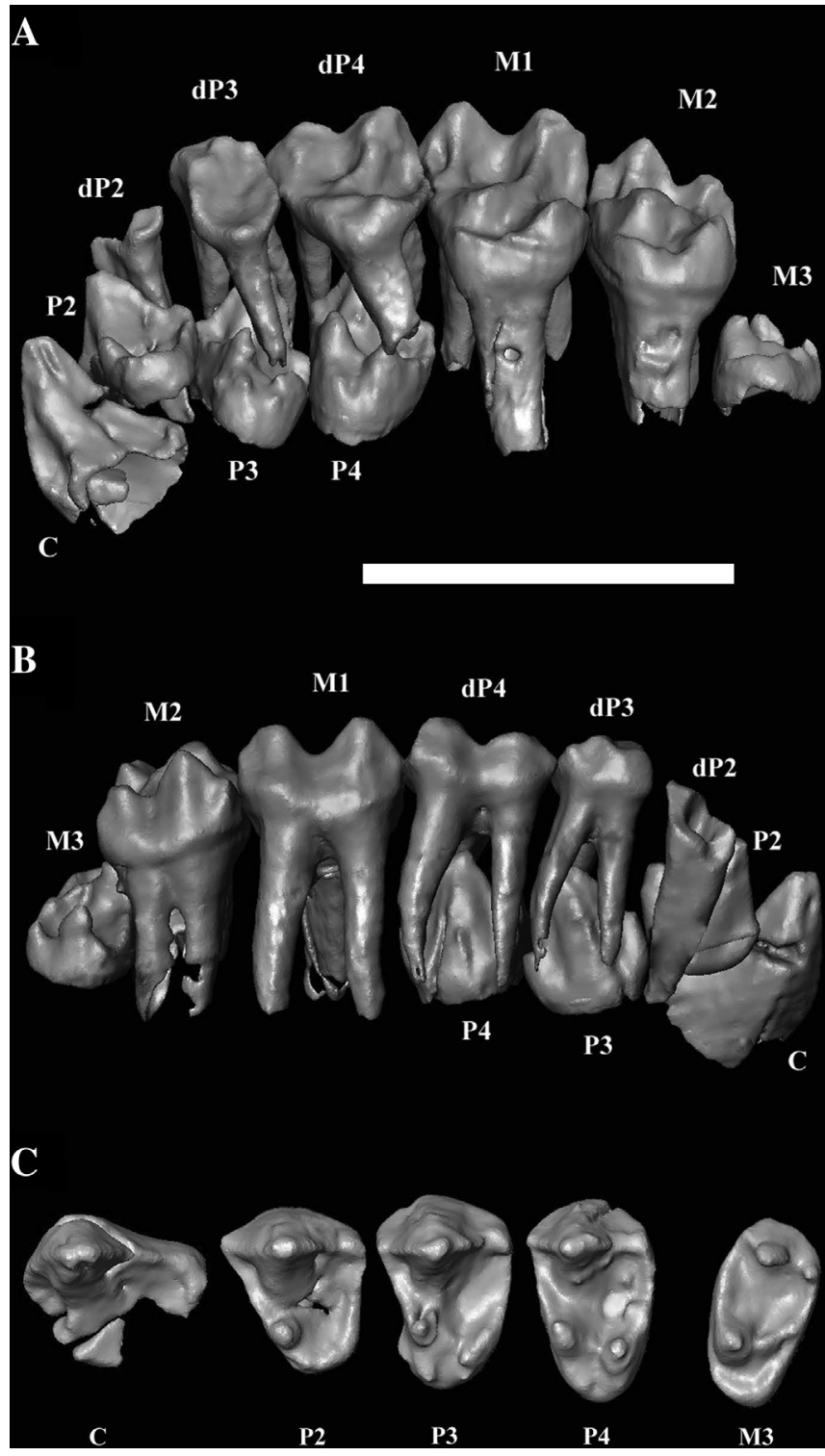

Figure 8. Three views of the preserved left-side dentition of MPM-PV 3505. A, lingual and partially occlusal view with all teeth in situ; B, buccal view with all teeth in situ; C, occlusal view of permanent teeth with all teeth rotated and translated into a common occlusal plane. All teeth reconstructed from CT scans. Scale bar $=1 \mathrm{~cm}$. 


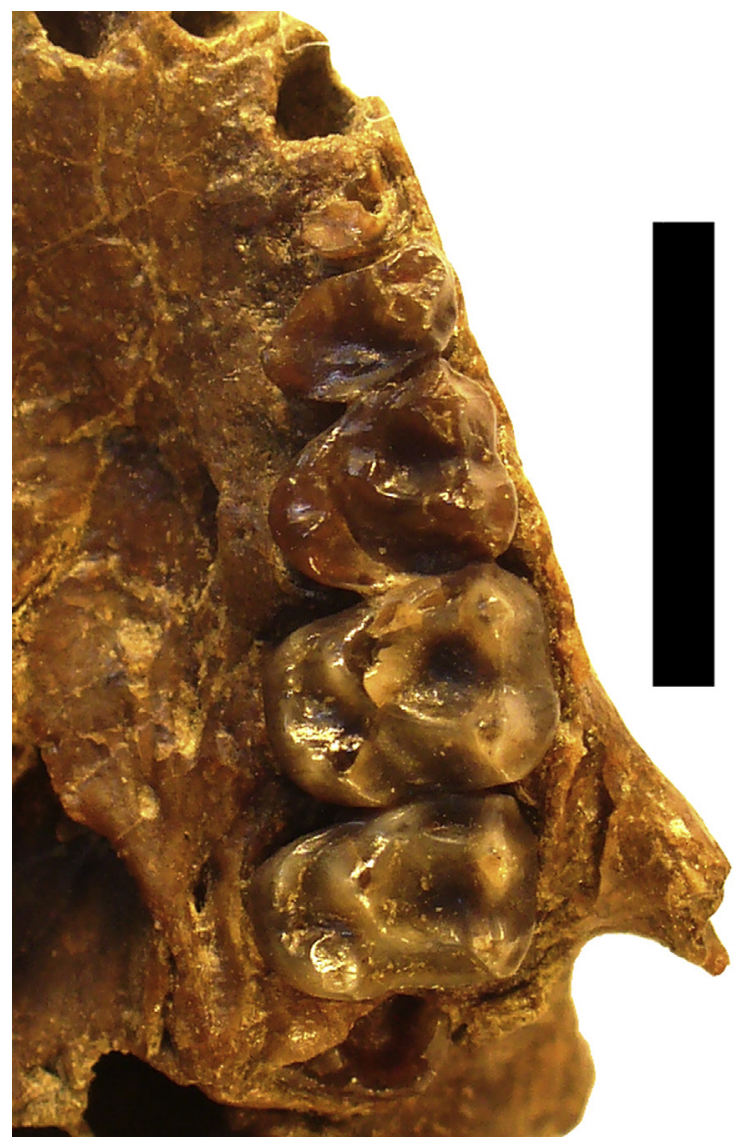

Figure 9. Occlusal view of the upper teeth on the left side of the palate of MPM-PV 3505. Scale bar $=1 \mathrm{~cm}$.

$\mathrm{dP}^{2}-\mathrm{dP}^{4}$ are erupted and in occlusion. Wear on the deciduous premolars decreases from $\mathrm{dP}^{2}$, through $\mathrm{dP}^{3}$, to $\mathrm{dP}^{4}$, suggesting a deciduous eruptive sequence of $\mathrm{dP}^{2}, \mathrm{dP}^{3}, \mathrm{dP}^{4}$, as in extant platyrrhines (Byrd, 1979, 1981; Smith, 1989). Also visible in the CT cross section are $\mathrm{P}^{2}-\mathrm{P}^{4}$ (Fig. 7). Each sits dorsolingual to the deciduous

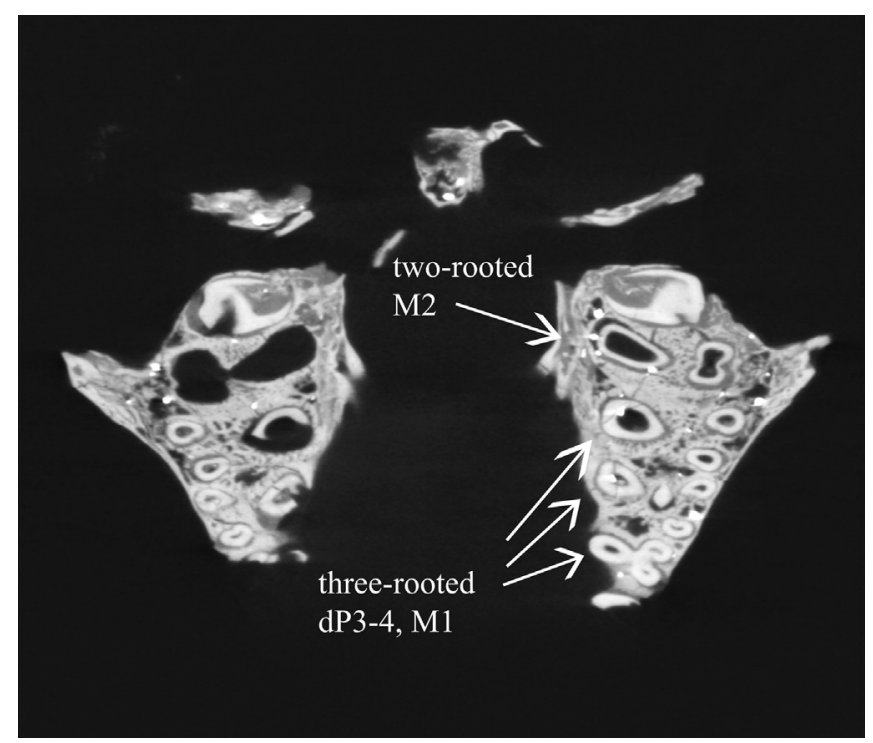

Figure 10. Transverse section through palate of MPM-PV 3505 showing the roots of deciduous premolars and permanent molars. tooth it would have replaced. The $\mathrm{P}^{2}$ is very close to the alveolar margin, $\mathrm{P}^{4}$ is not as close to the alveolar margin, and $\mathrm{P}^{3}$ is higher still and wedged in between $\mathrm{P}^{2}$ and $\mathrm{P}^{4}$. Based on these positions, the presumptive eruption pattern of the upper premolars would have been $\mathrm{P}^{2}, \mathrm{P}^{4}, \mathrm{P}^{3}$. The $\mathrm{P}^{4}, \mathrm{P}^{3}$ sequence was said to occur only in Lagothrix and Ateles among extant platyrrhines (Henderson, 2007). However, Byrd (1979) reported a $\mathrm{P}^{2}, \mathrm{P}^{4}, \mathrm{P}^{3}$ eruption sequence in some species or individuals of Callicebus, Alouatta, Saimiri, Callithrix, and Saguinus. Wear on the molars is slight. It is heavier on $\mathrm{M}^{1}$ than on $\mathrm{M}^{2}$, suggesting the molar eruption sequence was $\mathrm{M}^{1}$ followed by $\mathrm{M}^{2}$, then finally $\mathrm{M}^{3}$.

Based upon eruptive stage and tooth wear, the probable eruption sequence for the permanent dentition was: $\left(\mathrm{M}^{1}, \mathrm{I}^{1}, \mathrm{I}^{2}\right), \mathrm{M}^{2}, \mathrm{P}^{2}$, $\mathrm{P}^{4}, \mathrm{P}^{3},\left(\mathrm{M}^{3}, \mathrm{C}^{1}\right)$ (parentheses around tooth loci reflect sequence uncertainty within the parentheses). The $\mathrm{M}^{3}$ could actually appear anywhere in the sequence after $\mathrm{M}^{2}$, as could the canine, and we do not know which of the two $\left(\mathrm{M}^{3}\right.$ or $\left.\mathrm{C}^{1}\right)$ would have erupted first. Both $\mathrm{M}^{3} \mathrm{~s}$ are partly exposed in their crypts but were not yet erupted. In almost all platyrrhines for which dental eruption sequence is known, the $\mathrm{M}^{1}$ erupts before the permanent incisors (Smith, 1989; Henderson, 2007) as is also the case in Homunculus. MPM-PV 3505 clearly does not follow the apomorphic condition of Aotus, in which $\mathrm{M}^{2}$ and $\mathrm{M}^{3}$ both erupt before any of the permanent incisors (Byrd, 1979).

Comparison of MPM-PV 3505 with other primate specimens from the Santa Cruz Formation

Dental comparisons In most of the above-mentioned cranial specimens (MACN-A 5968, MPM-PV 3702, CORD-PZ 1130) the dentitions are heavily worn and only the general proportions of the teeth, not the anatomical details, can be discerned. Therefore, occlusal comparisons are mainly amongst MPM-PV 3505, MPMPV 5000, and MPM-PV 1607. The comparative sample is considerably larger with respect to dental size and proportions. Taking up the occlusal comparisons first, except for the incisors (absent) and the $\mathrm{P}^{4}$ (damaged), the same upper tooth loci are represented in MPM-PV 3505 and MPM-PV 5000, and many of the tooth roots are preserved even when the crown is missing. We find no variation in the details of occlusal anatomy between MPM-PV 3505 and the two specimens that form the hyopodigm of ' $K$. blakei' (MPM-PV 5000 and MPM-PV 1607). The above detailed anatomical description of the permanent premolars and molars of MPM-PV 3505 matches nearly perfectly the dentition of MPM-PV 5000. The one difference between the two is that the lingual cingulum of MPM-PV 5000 is slightly more pronounced than that of MPM-PV 3505. However, the lingual cingulum in MPM-PV 1607 (the referred specimen from KAN) is at least as well developed as in MPM-PV 3505. MPM-PV 5000 and MPM-PV 3505 lack a hypocone on $\mathrm{M}^{3}$, but one appears to be present on MPM-PV 1607 (Tejedor et al., 2006, Fig. 1F).

Dental shape differences were also examined with dental dimensions taken from a larger sample of Santa Cruz Formation primate upper molars collected by the Soria-Fleagle-MACN (Fleagle et al., 1988) expeditions of the 1980s-1990s (specimens at MACN), CORD-PZ 1130, and specimens collected by La Plata-Duke expeditions since 2003 (Table 1 ). Tables $3-5$ reveal only minor differences in size and shape in this sample as a whole. As illustrated in Fig. 11, the range of the Santa Cruz Formation upper molar dimensions is similar to that of a geographically restricted sample of a single subspecies of extant spider monkey, Ateles geoffroyi vellerosus. This is especially notable, given that this collection of fossil specimens spans a temporal interval of 0.7 million years or more. Size-free variation in the sample can be expressed as the coefficient of variation (CV). Table 6 summarizes the sample CVs for Santacrucian 
Table 3

Dimensions of the upper molars of primates from the Santa Cruz Formation used in Figs. 11 and 12.

\begin{tabular}{|c|c|c|c|c|c|}
\hline Specimen & Locality & $M^{1} M^{a}$ & $\mathrm{M}^{1} \mathrm{BL}$ & $\mathrm{M}^{2} \mathrm{MD}$ & $\mathrm{M}^{2} \mathrm{BL}$ \\
\hline CORD-PZ 1130 & Puesto Estancia La Costa & 3.77 & - & 3.75 & - \\
\hline MACN SC-334 & $\begin{array}{l}\text { Cerro Observatorio } \\
\text { nivel } 13 \text { ( } 43.1 \mathrm{~m} \text { level })\end{array}$ & - & - & 3.98 & 5.34 \\
\hline MACN SC-337 & $\begin{array}{l}\text { Cerro Observatorio, } \\
\text { nivel } 19 \text { ( } 28.9 \text { m level })\end{array}$ & - & - & 3.83 & 5.17 \\
\hline MACN SC-342 & $\begin{array}{l}\text { Monte Observación, } \\
\text { nivel } 54(94.5 \mathrm{~m})\end{array}$ & - & - & 3.78 & 5.42 \\
\hline MACN SC-3112 & $\begin{array}{l}\text { Cerro Observatorio, } \\
\text { nivel } 19 \text { ( } 28.9 \mathrm{~m} \text { level })\end{array}$ & - & - & 4.01 & - \\
\hline MPM-PV 3501 & Puesto Estancia La Costa & 4.27 & 6.20 & 4.15 & 6.06 \\
\hline MPM-PV 3502 & Killik Aike Norte & 4.19 & 6.28 & 4.15 & 5.91 \\
\hline MPM-PV 3503 & Puesto Estancia La Costa & 4.59 & 6.15 & 3.91 & 6.07 \\
\hline MPM-PV 3505 & Puesto Estancia La Costa & 4.16 & 5.74 & 3.65 & 5.61 \\
\hline MPM-PV $1607^{c}$ & Killik Aike Norte & 4.10 & 5.70 & 3.70 & 4.90 \\
\hline MPM-PV 5000 & Killik Aike Norte & (3.91) & 5.26 & 3.91 & 4.98 \\
\hline
\end{tabular}

${ }^{a}$ MD: mesiodistal, BL: buccolingual. Values in parentheses represent estimates from broken teeth.

$\mathrm{b}$ Cerro Observatorio $=$ Monte Observación of older literature, meters above base of the Santa Cruz Formation at Cerro Observatorio are given in Bown and Fleagle (1993).

${ }^{\text {c }}$ MPM-PV 1607 measurements from Tejedor et al. (2006).

upper molars compared with the same dimensions in large samples of 12 extant platyrrhine species. Variation in the mesiodistal dimensions of the SCF primate sample as a whole is comparable with the variation found in these samples of extant species. The sample variation for the buccolingual dimensions of SCF primates is somewhat large for a single platyrrhine species, especially considering the small sample size. In particular, the two specimens that have the buccolingually narrowest upper second molars are the holotype and paratype of K. blakei, MPM-PV 5000 and MPM-PV 1607 , respectively. The remaining specimens in the sample, including another specimen from Killik Aike Norte (MPM-PV 3502), MPM-PV 3505, and other specimens from PLC (MPM-PV 3503; shown in Kay et al., 2012) and elsewhere in the Santa Cruz Formation have somewhat buccolingually broader $\mathrm{M}^{2} \mathrm{~s}$. Nevertheless a similar range of variation is observed when $\mathrm{M}^{1}-\mathrm{M}^{2}$ dimensions are considered jointly in a principal components analysis (Fig. 12). Inclusion of MPM-PV 1607 and MPM-PV 5000 within the sample does not present more variation than would be expected from one

Table 4

Comparison of MPM-PV 3505 M with other molar specimens ${ }^{\mathrm{a}}$ of Homunculus.

\begin{tabular}{|c|c|c|}
\hline $\begin{array}{l}\text { Specimen } \\
\text { compared }\end{array}$ & $\begin{array}{c}\text { Morphology of } \\
\text { specimen compared }\end{array}$ & $\begin{array}{l}\text { Additional information } \\
\text { for MPM-PV } 3505\end{array}$ \\
\hline $\begin{array}{l}\text { CORD-PZ } 1130 \\
\quad \text { (Tauber, 1991) }\end{array}$ & $\begin{array}{l}\text { Similar proportions but } \\
\text { too worn to discern } \\
\text { occlusal details }\end{array}$ & - \\
\hline $\begin{array}{l}\text { *MACN SC-274 } \\
\quad\left(\text { an } \mathrm{M}^{3}\right)\end{array}$ & $\begin{array}{l}\text { Has a small metaconule; } \\
\text { hypocone present }\end{array}$ & $\begin{array}{l}\text { Variable metaconule size; } \\
\text { hypocone absent }\end{array}$ \\
\hline *MACN SC-334 & $\begin{array}{l}\text { More poorly developed } \\
\text { lingual cingulum }\end{array}$ & - \\
\hline${ }^{*} \mathrm{MACN}$ SC-342 & $\begin{array}{l}\text { Better developed lingual } \\
\text { cingulum (distinct } \\
\text { cingulum cusp lingual } \\
\text { to the protocone) }\end{array}$ & - \\
\hline MPM-PV 3502 & $\begin{array}{l}\text { Similar proportions but } \\
\text { too worn to discern } \\
\text { occlusal details }\end{array}$ & - \\
\hline $\begin{array}{l}\text { MPM-PV 3503, } \\
\text { Undescribed, } \\
\text { lightly worn } \mathrm{M}^{1-3}\end{array}$ & Lacks $\mathrm{M}^{3}$ hypocone & Lacks $\mathrm{M}^{3}$ hypocone \\
\hline
\end{tabular}

Table 5

Details of the $\mathrm{M}^{1}$ and $\mathrm{M}^{2}$ in the PLC and KAN primate sample.

\begin{tabular}{ll}
\hline $\mathrm{M}^{1}$ only & Paracone $\approx$ metacone \\
$\mathrm{M}^{2}$ only & Metacone < protocone \\
Both $\mathrm{M}^{1}$ and $\mathrm{M}^{2}$ & Protocone widely separate from paracone; \\
& postparacrista and premetacrista >> than \\
& preparacrista and postmetacrista \\
& Buccal crests aligned mesiodistally \\
& No metastyle \\
& Small paraconules with distinct cristae \\
& No mesial cingulum, except where \\
& preparaconule crista is continuous with \\
& preprotocrista (at mesial margin of tooth) \\
& Postparaconule crista runs buccally, \\
& continuous with anterior transverse crista \\
& arising from paracone \\
& No metaconule \\
& Strong preprotocrista joins preparaconule \\
& crista \\
& Postprotocrista runs diagonally to base of \\
& metacone, reaches sharp posterior transverse \\
crista of metacone & No distal spur on postprotocrista \\
Hypocone is large, distal, and slightly lingual \\
to protocone \\
Prominent prehypocrista meets wall of \\
postprotocrista; talon closed off lingually \\
Strong posthypocrista confluent with \\
distal cingulum \\
Weak buccal cingulum \\
Well-developed lingual cingulum from apex of \\
hypocone lingually around base of protocone to \\
join reach preprotocrista; wide cingulum shelf \\
with no cuspal adornment \\
\\
\end{tabular}

species, as the spread of values is no more than in our cluster of A. geoffroyi specimens.

Cranial comparisons MPM-PV 3505 is, in most respects, very similar to CORD-PZ 1130 from Puesto Estancia La Costa (Tauber, 1991), MPM-PV 5000 from Killik Aike Norte (Tejedor et al., 2006), and to other specimens of Homunculus from PLC and KAN (Kay et al., 2012).

All crania from the SCF are very similar in the proportions and arrangement of the cranial bones, the shape and orientation of the orbits and nasal aperture, and the size and position of the facial foramina. The orbits are rounded (versus oval with the long axis dorsoventrally) in all specimens and the orbits are less convergent than in most extant platyrrhines (except callitrichines), and in this respect resemble Early Miocene Tremacebus and Dolichocebus (Hershkovitz, 1974; Ross, 1995; Kay et al., 2008). The scalloped posterior margin of the palate and lateral position of the roots of the pterygoid plates are similar. The position of the lacrimal foramen and of the nasolacrimal duct is similar. A small infraorbital foramen is present on all specimens and similarly positioned on the rostrum above the posterior premolars $\left(\mathrm{dP}^{3}-\mathrm{dP}^{4}\right.$ or $\left.\mathrm{P}^{3}-\mathrm{P}^{4}\right)$. There is a similar degree of postorbital closure, with a slit-like inferior orbital fissure and a small, round lateral orbital fissure. In all specimens, the zygomatico-facial foramina are small. Some sample variation is present in the arrangement of the bones on the anteromedial aspect of the orbit; the frontal is in contact with the maxilla in some cases and not in others but this difference is not unusual in a population of an extant platyrrhine, like species of Alouatta. In short, all crania from the SCF are very similar in the proportions and arrangement of the cranial bones, the shape and orientation of the orbits and nasal aperture, and the size and position of the facial foramina.

Table 2 gives basic cranial dimensions of the best-preserved Santa Cruz primate specimens. Of course, MPM-PV 3505 is a juvenile whilst the other specimens are dentally adult. Among the 

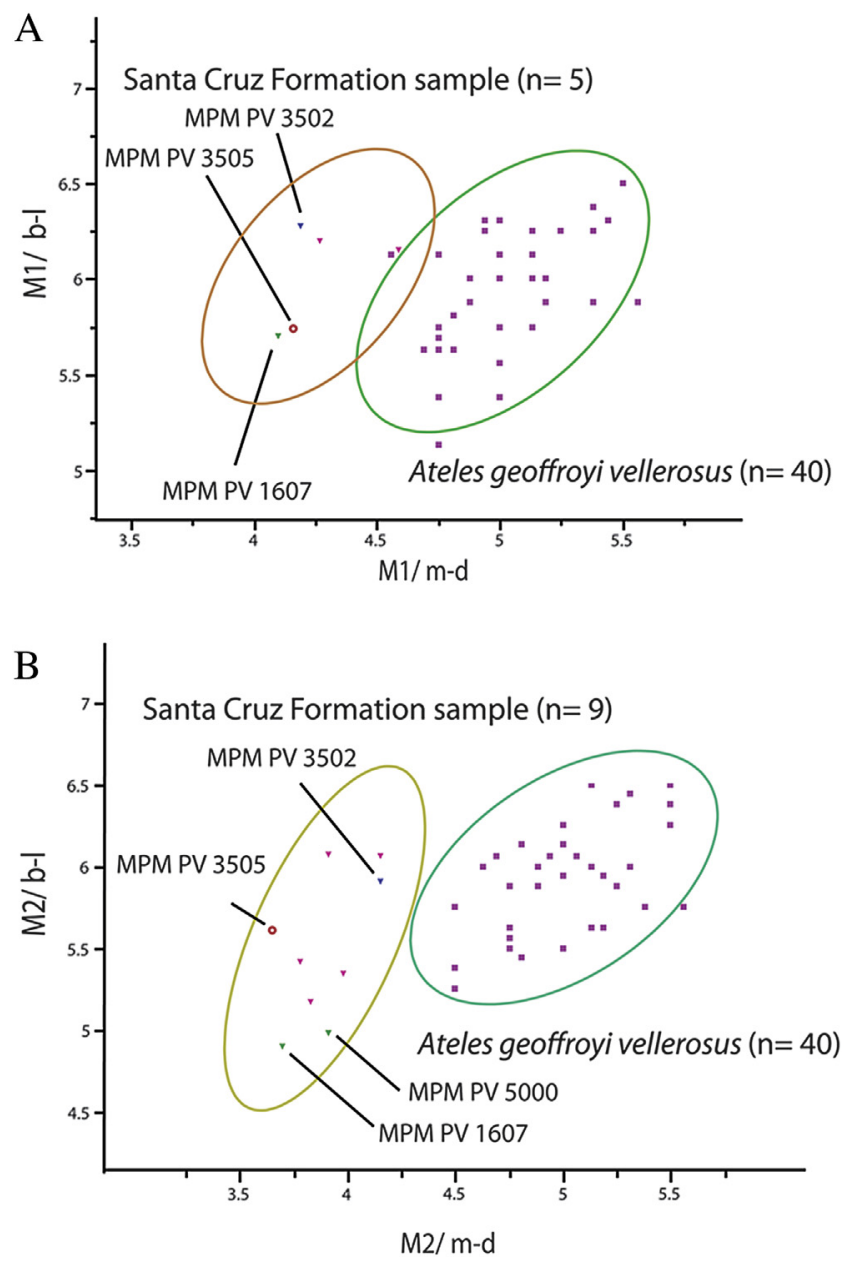

Figure 11. Bivariate plot showing the scatter in molar dimensions in Santacrucian primates and an extant platyrrhine, Ateles geoffroyi vellerosus $(n=20)$. The latter sample is composed of ten male and ten female specimens, all from Mexico and collected by a single collector, during a single expedition, with specimens housed at the American Museum of Natural History and the National Museum of Natural History (Plavcan, 1990). MD: greatest mesiodistal crown dimension in occlusal view, BL: greatest buccolingual crown dimension in occlusal view. A, upper first molar; B, upper second molar.

latter, MPM-PV 5000 is a young dental-adult, with minor occlusal wear on the upper molars and premolars, whereas the other specimens exhibit heavy dental wear. Platyrrhines are known to experience several changes during cranial development, including some elongation of the rostrum (e.g., Corner and Richtsmeier, 1992). This tendency would suggest that, had MPM-PV 3505 survived to adulthood, the rostrum might have been more elongate compared with that of MPM-PV 5000.

Inter-orbital breadth is quite reduced in MPM-PV 5000, CORDPZ 1130 (RFK, Personal observation), and other Homunculus specimens, including MPM-PV 3502 from KAN and MACN-A 5968 from PLC. This dimension is slightly narrower in MPM-PV 3505 than in the other specimens, as expected by its younger ontogenetic age. The size and shape of the nasal aperture are similar in MPM-PV 3505, MPM-PV 5000, and MPM-PV 3502 (not preserved in CORD$\mathrm{PZ} \mathrm{1130).} \mathrm{Also} \mathrm{similar} \mathrm{in} \mathrm{all} \mathrm{specimens} \mathrm{are} \mathrm{the} \mathrm{position} \mathrm{(above}$ $\mathrm{M}^{2}$ ) and robusticity of the anterior root of the zygomatic arch, and the height of the orbit above the alveolar process of the maxilla.

Given the proposed generic-level distinction between MPM-PV 5000 and all other Santacrucian primate crania, it would seem important to pay special attention to such differences as have been proposed to separate MPM-PV 5000 from Homunculus. At first glance, these two crania appeared to have several differences in the detail of the palate shape and facial projection. The palate in MPM-PV 3505 appears broader (mediolaterally) relative to its length, lending a parabolic appearance to the upper dental arcade whereas that of MPM-PV 5000 appears narrower and longer and the postcanine rows appear to be nearly parallel. This, however, is a visual artifact due to different parts being broken away in the two specimens. We determined this by quantifying arcade shape angle, that is, the angle between the midline and 'tooth row orientation' (as measured from the mid-point on the mesial edge of the $\mathrm{I}^{1}$ alveolus to the mid-point on the posterior edge of $\mathrm{M}^{3}$ ). The values for arcade shape angle are $73^{\circ}$ for MPM-PV 3505 and $72^{\circ}$ for MPM-PV 5000. The apparent difference in palate shape reflects differential breakage.

There also appears to be a difference in the angle of facial projection between the two specimens. The face in MPM-PV 3505 appears to project slightly less than that of MPM-PV 5000. However, this again is a visual artifact due to slight breakage of the nasals in MPM-PV 3505. To quantify this, we defined facial projection as the angle between 'face orientation' (as measured from nasion to alveolare superior) and 'palate orientation' (as measured from alveolare superior to a line connecting the anterior edge of the right and left $\mathrm{M}^{1}$ ). This angle in MPM-PV 3505 is $42^{\circ}$ and in MPMPV 5000 it is $43^{\circ}$.

As already shown, all specimens have narrow interorbital dimensions, so this is not a distinguishing feature of MPM-PV 5000 from other SCF crania. Another proposed difference is positioning of the rostrum relative to the braincase (Fig. 13). Tejedor et al. (2006) stated that the face of MPM-PV 5000 is short, and the frontal bone is vertically oriented. On this basis they infer that MPM-PV 5000 had an enlarged anterior cranial fossa (and enlarged brain), whereas the frontal of Homunculus (CORD-PZ 1130) is sloping and the anterior cranial fossa was smaller (with a smaller brain). To establish the orientation of the frontal, one must determine how the rostrum is hafted onto the braincase. In Homunculus (e.g., CORD-PZ 1130), the rostrum is upwardly tilted relative to the braincase; a condition called airorhynchy (Tauber, 1991). Several other specimens from PLC and one from KAN (MPM-PV 3502) show this same configuration. Measuring airorhynchy depends on having an accurate way of placing the rostrum relative to the Frankfort horizontal. In the absence of a braincase, airorhynchy cannot be estimated in MPM-PV 5000. However, if one rotates the rostrum of MPM-PV 5000 into an anatomical position analogous to that of CORD-PZ 1130, it becomes clear that the facial projection of both are very similar and the frontal in MPM-PV 5000 would slope posteriorly, not be disposed vertically. Thus, the shape of the anterior cranal fossa would be similar in CORD-PZ 1130 and MPMPV 5000. In the absence of more compelling evidence, it appears that MPM-PV 5000 had a small anterior cranial fossa, similar in shape to that of CORD-PZ 1130.

\section{Discussion}

We find no compelling species-level differences in the available sample of cranial and maxillary dental specimens previously assigned to $H$. patagonicus and to ' $K$. blakei'. Although the former have slightly buccolingually broader teeth than the latter, the differences are not beyond what would be observed in a small sample of an extant species of platyrrhines. Furthermore, gross molar dimensions in the Santacrucian primate sample show no clear clusters that would support the presence of multiple taxa (Fig. 12). The $\mathrm{M}^{1}-\mathrm{M}^{2}$ of MPM-PV 3505 and MPM-PV 1607 resemble the upper molars from PLC (e.g., CORD-PZ 1130), assigned by all scholars without question to $H$. patagonicus. Furthermore, there are no cranial features that would permit us to sort the 'Killikaike' 
Table 6

Mean coefficient of variation ${ }^{\mathrm{a}}$ (CV, expressed as a percent) for 12 species of extant platyrrhines and several Santa Cruz specimens.

\begin{tabular}{|c|c|c|c|c|c|}
\hline \multirow[b]{2}{*}{$\begin{array}{l}\text { Tooth and } \\
\text { dimension }\end{array}$} & \multicolumn{2}{|c|}{ Bias corrected CV for extants } & \multicolumn{3}{|c|}{ Santa Cruz primate sample } \\
\hline & Mean CV & Range & Mean CV & SE & $\mathrm{N}$ \\
\hline $\mathrm{M}^{1}$ mesiodistal & 4.31 & $1.74-6.88$ & 6.00 & 1.80 & 7 \\
\hline $\mathrm{M}^{1}$ buccolingual & 4.37 & $1.92-6.83$ & 4.77 & 1.77 & 5 \\
\hline $\mathrm{M}^{2}$ mesiodistal & 4.60 & $2.41-6.79$ & 4.45 & 1.02 & 11 \\
\hline $\mathrm{M}^{2}$ buccolingual & 4.66 & $1.35-7.97$ & 8.34 & 2.16 & 9 \\
\hline
\end{tabular}

${ }^{a} \mathrm{CV}$ is reported with a correction for sample size and the standard error of the $\mathrm{CV}$ is calculated following Sokal and Rohlf (1981:139).

specimens apart from those of Homunculus. Therefore, we favor the assignment of all cranial specimens to a single species, $H$. patagonicus, with 'K. blakei' being a subjective junior synonym of the latter.

We remain cautious in this assignment because the holotype of $H$. patagonicus is a lower jaw (as is the proposed neotype) and no associated lower jaw and cranium have ever been found for this taxon. The situation remains as it was when Bluntschli published his descriptive monograph: "The type of the genus is based on a lower jaw and there are no associated finds of the cranium and jaws together" (Bluntschli, 1931:817 [RFK translation]).

It has been suggested that Homunculus and 'Killikaike' are early representatives of the extant families Pitheciidae and Cebidae, respectively. The evidence brought forward here, especially the near identity of the dental structure, suggests that the two are synonymous. Therefore, the broader argument about the familial affinities of these Santacrucian monkeys must be revisited. Our discussion first needs to be informed by a consideration of the phylogenetic placement of the extant taxa Aotus and Callicebus. These two taxa often are considered to be basal members of crown

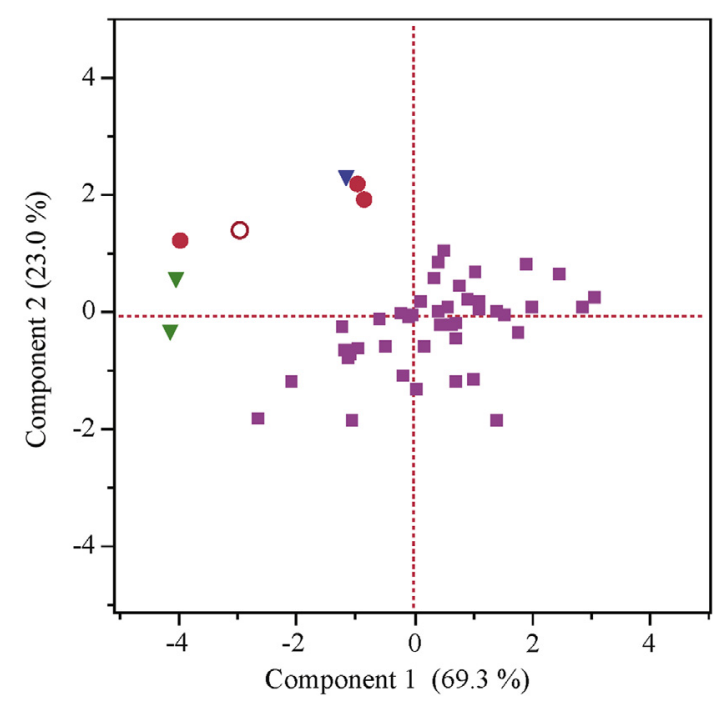

Figure 12. Principal components analysis of first and second upper molar dimensions of all Santa Cruz Formation primates, published and unpublished, for which both $\mathrm{M}^{1}$ and $\mathrm{M}^{2}$ are preserved. A sample of Ateles geoffroyi vellerosus, an extant atelid represented with squares, is presented for comparative purposes. The first two factors account for $92.3 \%$ of the variance. The first axis shows nearly equal eigenvalues for all four dimensions, ranging from +0.45 to +0.53 . Larger tooth size gives a larger PC1 eigenvector. The second axis has positive eigenvalue loadings for teeth that are broader buccolingually (mesiodistal eigenvalues range from -0.47 to -0.48 ; buccolingial eigenvalues range from +0.41 to +0.61 ). Proportionally broader teeth have larger values on PC1. Reverse triangles are specimens from Killik Aike Norte; circles represent specimens from Puesto Estancia La Costa. The two samples overlap completely and the overall spread of values is similar to that of the living taxon.
Pitheciidae (Rosenberger, 2011; Rosenberger and Tejedor, 2013; Tejedor, 2013). While molecular phylogenetic studies affirm the pitheciid affinities of Callicebus, it is now clear that Aotus is a member of the Cebidae, either basal to the subfamily Cebinae, which includes Saimiri and Cebus, or a basal member of the callitrichine clade, which includes marmosets and tamarins (e.g., Opazo et al., 2006; Osterholz et al., 2009; Wildman et al., 2009; Perelman et al., 2011). Therefore, an argument that Homunculus "closely resembles the typical pattern of Aotus" (Rosenberger and Tejedor, 2013:15) provides no evidence for the pitheciid affinities of Homunculus. Indeed, taken to its logical conclusion, such a claim (which we do not make) would unite Homunculus with Cebinae. Here we argue that neither Homunculus nor 'Killikaike' should be considered early representatives of extant platyrrhine families. This argument is supported by three main points.

First, lower incisor structure figures prominently in the suggestions of pitheciid affinities for Homunculus (e.g., Rosenberger et al., 2009). Homunculus shares with Callicebus moderately elongate lower incisors (from the cemento-enamel junction to the cusp tip) (Perry et al., 2010; Kay et al., 2012). This feature is likely an adaptation for producing a vertical load by means of anterosuperior jaw movement. Homunculus, like Callicebus, certainly used its incisors for powerful incision, although whether for tree scoring, fruit husking, or some other purpose is not clear, since this adaptation was acquired independently also in the living tamarin Saguinus, and perhaps also in the Oligocene anthropoid Aegyptopithecus.

Second, cebine affinities of 'Killikaike' are supported, in part, by its supposed small interorbital breadth (IOB). This feature is definitely observed in MPM-PV 5000 ('Killikaike') but does not unite cebines with MPM-PV 5000 to the exclusion of other Homunculus specimens, as claimed by Tejedor and Rosenberger (2008). As shown in Table 2, we have five specimens of Homunculus for which IOB is measurable. The mean IOB is $4.9 \mathrm{~mm}$ with a range of $4.2-5.5 \mathrm{~mm}$. The value for MPM-PV 5000 is $4.4 \mathrm{~mm}$, slightly below the species mean. The IOB of our juvenile specimen is $3.53 \mathrm{~mm}$. Extant Saimiri has an adult mean IOB of $3.47 \mathrm{~mm}(n=10$, range $=3.00-3.90$; RFK, Unpublished data). Saimiri specimens at a dental age similar to our juvenile Homunculus (with $\mathrm{M}^{2}$ erupted, but not $\mathrm{M}^{3} ; n=6$ ) have a mean of $2.85 \mathrm{~mm}$. If the growth of this dimension follows that of Saimiri, the adult IOB in our juvenile would have been $4.3 \mathrm{~mm}$, well within the range of the other specimens.

Third and finally, some claims for a supposed morphological similarity between MPM-PV 5000 and cebines stems from an overinterpretation of the cranial evidence observed in MPM-PV 5000, namely uncertainty about the alignment of the rostrum on the braincase. Other specimens of Homunculus that preserve both the face and braincase exhibit an upward tilt of the rostrum on the braincase (airorhinchy) (Tauber, 1991; Kay et al., 2012). In the absence of the neurocranium, the position of the MPM-PV 5000 face is uncertain but if it is upwardly tilted like Homunculus (Kay et al., 2012), then the frontal bone would not be 'vaulted' and the anterior cranial fossa would not be enlarged (and cebine-like) as claimed by Tejedor and colleagues (Tejedor et al., 2006; Tejedor and Rosenberger, 2008). The uncertainty of the facial hafting in MPMPV 5000 also casts doubt on the claim that MPM-PV 5000 had a shortened face, another supposed similarity with cebines.

A larger point should be emphasized, namely that given the documented levels of homoplasy in morphological data for platyrrhines, individual structural characteristics can be advanced as derived characters to support practically any phylogenetic arrangement of the fossils (Sanchez-Villagra and Williams, 1998). Only an exhaustive phylogenetic analysis of Oligocene to recent platyrrhines can establish the most parsimonious arrangement of 
A
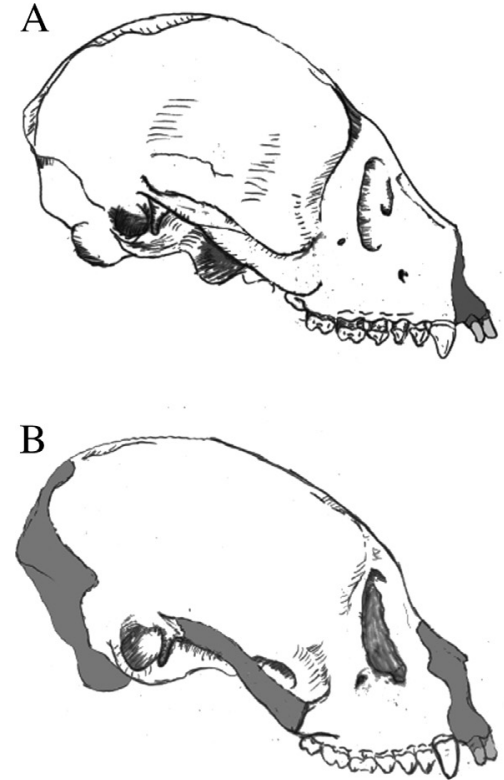

$\mathrm{C}$

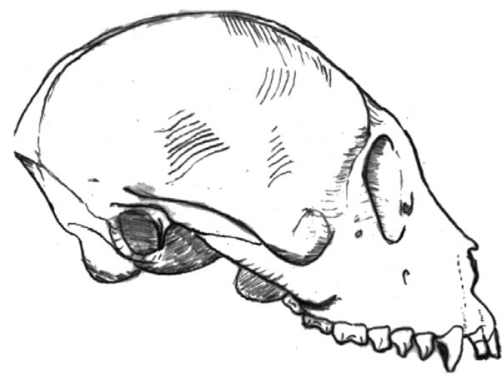

$\mathrm{D}$

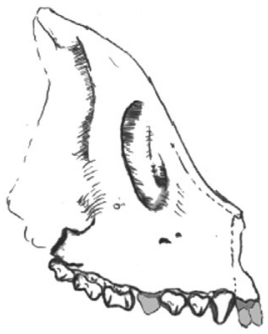

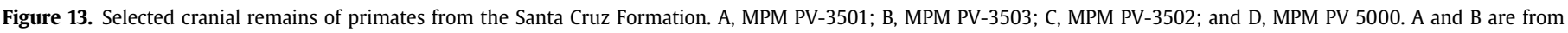
Puesto Estancia La Costa; C and D are from Killik Aike Norte. Scale bar $=2 \mathrm{~cm}$.

the fossil taxa in relation to the living radiations of Platyrrhini. Such an analysis has been undertaken recently and it strongly supports the view that Homunculus and other Early Miocene platyrrhines are stem forms not specially related to any of the three living families (Kay, 2014; see also Kay, Fleagle and colleagues; Kay et al., 2008; Kay and Fleagle, 2010).

MPM-PV 3505 provides the first information about the dental eruption sequence in an Early Miocene platyrrhine. The eruption sequence of the premolars is: $\mathrm{P}^{2}, \mathrm{P}^{4}, \mathrm{P}^{3}$. The $\mathrm{P}^{2}, \mathrm{P}^{4}, \mathrm{P}^{3}$ eruption sequence also is common in extant platyrrhines but the clade exhibits substantial within-species variation, as the three teeth erupt at very nearly the same time. This pattern also is identical to that of the Oligocene stem anthropoids Apidium phiomense and Simonsius grangeri (Kay and Simons, 1983).

In MPM-PV 3505, the incisors erupted before $\mathrm{M}^{3}$. This is the most common pattern among extant platyrrhines: the third molar is among the last of the permanent teeth to erupt in species of all extant platyrrhines clades (except in callitrichines that lack a third molar) (Byrd, 1979). Aotus is the exception to this rule: in Aotus, the molars erupt before the permanent incisors (see also Byrd, 1979; Kay and Simons, 1983; Kay and Meldrum, 1997). Because all living platyrrhines except Aotus exhibit early emergence of the incisors relative to the molars, the simplest explanation is that this pattern of early incisor emergence was already present in the last common ancestor of the clade and that the Aotus pattern is an autapomorphy. Indeed, early incisor emergence relative to the third molar was a developmental pattern that occurred even deeper in the anthropoid clade: a conclusion that is supported by the ubiquitous eruption of the incisors before $\mathrm{M}^{3}$ in all known catarrhines (Smith, 1989), and among Late Eocene-Early Oligocene African stem anthropoids (Kay and Simons, 1983).

Henderson (2007) offered a contrasting interpretation that the last common ancestor of platyrrhines had a dental eruption sequence like that of extant Aotus. In support of this conclusion, she cited Takai et al. (2000) who claimed that the Aotus-like early eruption of all the molars also occurs in the earliest known platyrrhine Branisella boliviana (Late Oligocene, Bolivia). However, the specimens of Branisella used to infer the eruption sequence (MNHN-Bol-V 5310 and 5311) are insufficient to make such a determination. Both specimens are of dental adults and Takai et al. (2000) reconstructed the tooth eruption sequence based on the degree of wear on each tooth. In our experience, the relative degree of wear within tooth classes does give some indication about the eruption sequence, e.g., the first molar generally is more worn than the second and so on. However, inference about eruptive sequence based on relative wear between tooth classes (incisors versus molars in this instance) is unreliable. Food is processed differently at different tooth loci; therefore, heavy wear on the molars combined with lighter wear on the incisors might indicate that tough and/or gritty foods are preferentially processed on the molars. A case in point is the neotype of Homunculus. Its heavily worn molars would lead us to an erroneous inference that the molars erupted before the incisors, but the new juvenile specimen allows us to say with confidence that early molar eruption is not the pattern for Homunculus.

When a diet includes tough or gritty foods, molarized deciduous premolars may be seen as a functional solution to prolonging deciduous tooth functionality in juveniles. Among folivorous strepsirrhines, there are several different tooth eruption sequences and paces (Godfrey et al., 2004, 2005). These may represent alternative strategies for maximizing functional tooth surface and for minimizing the inevitable loss of dental functionality when deciduous premolars are shed (Godfrey et al., 2005). In platyrrhines, folivory does not predict tooth eruption sequence (Henderson, 2007). The deciduous premolars in Homunculus are highly molarized (as is typically the case among extant platyrrhines, and indeed most primates) and routine trituration of tough or gritty foods probably was achieved by the deciduous premolars well before the molars erupted. The diet of Homunculus perhaps was sufficiently tough or gritty to warrant delaying molar eruption so as to maintain the 
availability of functional cheek teeth for a longer part of the animal's life. In Homunculus, the advantage of prolonging the functional life of the cheek teeth likely outweighed any advantage of erupting the molars early.

\section{Summary and conclusions}

The new cranial specimen, MPM-PV 3505, provides the first evidence of juvenile primate cranial anatomy for the Early Miocene Santa Cruz Formation of Argentina. The specimen is from the most productive locality for specimens assigned to $H$. patagonicus (Puesto Estancia La Costa, PLC) and closely resembles their adult crania, with most of the differences accounted for by the incomplete stage of growth. We allocate the new specimen to $H$. patagonicus based on resemblance to other primate material from PLC, CORD-PZ 1130 and MACN-A 5968, which were previously allocated to this species (e.g., Tejedor and Rosenberger, 2008). Furthermore, we find only minor dental differences among the dentitions of MPM-PV 3505, a sample of specimens referred to $H$. patagonicus from PLC and elsewhere, and that of the nominal taxon 'K. blakei' from Killik Aike Norte. These differences are in the shape of the upper molars and not in the structural details; the dentitions are virtually identical despite a difference of roughly 0.7 million years in the ages of the two localities. Furthermore, the metric variation in molar dimensions in the sample of primates from the Santa Cruz Formation is no more than that seen in a moderately sexually dimorphic subspecies of extant platyrrhine. This is despite a broad temporal range for H. patagonicus (up to two million years when all specimens are included). Dental morphology provides no support for the existence of more than one genus of Santa Cruz Formation platyrrhine. ${ }^{1}$ The further claim that Homunculus and 'Killikaike' represent early members of two extant families of platyrrhines hinges on an unreliable interpretation of the position of the rostrum relative to the braincase, resulting in the claim that the brain is larger in 'Killikaike' (cebid-like) than it is in Homunculus.

MPM-PV 3505 reinforces previous inferences about diet and activity pattern in Homunculus: it was likely a diurnal, folivorefrugivore that ingested foods containing silica phytoliths or invested with large quantities of dietary grit (Perry et al., 2010; Kay et al., 2012). The new specimen is important as it provides new insight into the evolution of dental eruption sequences in platyrrhines. MPM-PV 3505 does not fit the early molar eruption model proposed as primitive for platyrrhines. It is possible that the degree of molarization in the deciduous premolars was an adaptation for processing tough, gritty plant material prior to molar eruption. Perhaps the permanent molars were kept in reserve, extending the lifespan of functionally folivorous cheek teeth in the presence of abrasive foods.

\section{Acknowledgments}

We thank the Battini family for their generosity during eight field seasons at their Estancia. We thank the 2007 field crew: Leonel Acosta, Juan Carlos Fernicola, Richard Madden, Lucas Pomi, Francisco Prevosti, and Néstor Toledo. We thank the Museo Regional Provincial 'Padre M. J. Molina' (Rio Gallegos), the Museo Argentino de Ciencas Naturales 'Bernardino Rivadavia' (Buenos Aires), and the Museo de la Plata for allowing us to study specimens in their care. We thank two anonymous reviewers whose comments led to substantial improvements in the manuscript. This project was

\footnotetext{
1 An undescribed mandibular specimen from Puesto Estancia La Costa may belong to a new taxon, as noted by Kay et al. (2012).
}

funded by Agencia Nacional de Promoción Científica y Tecnológica (PICT 0143), CONICET (PIP 1054), UNLP (N647) to SFV; NSF (BCS0851272) to RFK, a National Geographic Society grant to SFV; and research funds from Duke University and Midwestern University to RFK and JMGP, respectively.

\section{References}

Ameghino, F., 1894. Enumération synoptique des espèces de mammifères fossiles des formations Eocènes de Patagonie. Bol. Acad. Nac. Cien. Córdoba 13, $259-451$.

Ameghino, F., 1904a. Nuevas especies de mamíferos cretáceos y Terciarios de la República Argentina. An. Soc. Cien. Argentina 56-58, 1-142.

Ameghino, F., 1904b. Recherches de morphologie phylogenetique sur les molaires superieures des ongules. An. Mus. Nac. de Buenos Aires Série 3 (3), 1-541.

Ashley-Montague, M.F., 1933. The anthropological significance of the pterion in the primates. Am. J. Phys. Anthropol. 13, 159-336.

Bluntschli, H., 1931. Homunculus patagonicus und die zugereihten Fossilfunde aus den Santa-Cruz-Schichten Patagoniens. Gegenbaurs Morphol. Jahrb. 67, $811-892$.

Bown, T.M., Fleagle, J.G., 1993. Systematics, biostratigraphy, and dental evolution of the Palaeothentidae, later Oligocene to early-middle Miocene (Deseadan-Santacrucian) caenolestoid marsupials of South America. J. Paleontol. 67, 1-76.

Byrd, K.E., 1979. Sequences and asymmetries of dental development and eruption in the Ceboidea. Ph.D. Dissertation, University of Washington.

Byrd, K.E., 1981. Sequences of dental ontogeny and callitrichid taxonomy. Primates 22, 103-118.

Cartmill, M., 1978. The orbital mosaic in prosimians and the use of variable traits in systematics. Folia Primatol. 30, 89-114.

Corner, B.D., Richtsmeier, J.T., 1992. Cranial growth in the squirrel monkey (Saimiri sciureus): A quantitative analysis using three dimensional coordinate data. Am. J. Phys. Anthropol. 87, 67-81.

Croft, D.A., Radic, J.P., Zurita, E., Charrier, R., Flynn, J.J., Wyss, A.R., 2003. A Miocene toxodontid (Mammalia: Notoungulata) from the sedimentary series of the Cura-Mallín Formation, Lonquimay. Chile. Rev. Geol. Chile 30, 285-298.

Fleagle, J.G., Buckley, G.A., Schloeder, M.E., 1988. New primate fossils from Monte Observación, Santa Cruz Formation (lower Miocene), Santa Cruz Province, Argentina. J. Vert. Paleontol. 8, 14A.

Fleagle, J.G., Perkins, M.E., Heizler, M.T., Nash, B., Bown, T.M., Tauber, A.A Dozo, M.T., Tejedor, M.F., 2012. Absolute and relative ages of fossil localities in the Santa Cruz and Pinturas Formations. In: Vizcaíno, S.F., Kay, R.F., Bargo, M.S. (Eds.), Early Miocene Paleobiology in Patagonia: High-Latitude Paleocommunities of the Santa Cruz Formation. Cambridge University Press, Cambridge, pp. $41-58$.

Godfrey, L.R., Samonds, K.E., Jungers, W.L., Sutherland, M.R., 2004. Ontogenetic correlates of diet in Malagasy primates. Am. J. Phys. Anthropol. 123, 250-276.

Godfrey, L.R., Samonds, K.E., Wright, P.C., King, S.J., 2005. Schultz's unruly rule: dental developmental sequences and schedules in small-bodied, folivorous lemurs. Folia Primatol. 76, 77-99.

Geoffroy Saint-Hilaire, É., 1812. Tableau des quadrumanes, 1. Ord. Quadrumanes. Ann. Mus. Hist. Nat. Paris 19, pp. 85-122.

Henderson, E., 2007. Platyrrhine dental eruption sequences. Am. J. Phys. Anthropol. $134,226-239$.

Hershkovitz, P., 1974. A new genus of late Oligocene monkey (Cebidae, Platyrrhini) with notes on postorbital closure and platyrrhine evolution. Folia Primatol. 21, 1-35.

Hershkovitz, P., 1981. Comparative anatomy of platyrrhine mandibular cheek teeth dpm4, pm4, m1, with particular reference to those of Homunculus (Cebidae) and comments on platyrrhine origins. Folia Primatol. 35, 179-217.

Kay, R.F., 2010. A new primate from the Early Miocene of Gran Barranca, Chubut Province, Argentina: Paleoecological implications. In: Madden, R.H., Vucetich, G., Carlini, A.A., Kay, R.F. (Eds.), The Paleontology of Gran Barranca: Evolution and Environmental Change through the Middle Cenozoic of Patagonia. Cambridge University Press, Cambridge, pp. 220-239.

Kay, R.F., 2014. Biogeography in deep time- What do phylogenetics, geology, and paleoclimate tell us about Miocene platyrrhine evolution? Mol. Phylogenet. Evol. http://dx.doi.org/10.1016/j.ympev.2013.12.002.

Kay, R.F., Fleagle, J.G., 2010. Stem taxa, homoplasy, long lineages and the phylogenetic position of Dolichocebus. J. Hum. Evol. 59, 218-222.

Kay, R.F., Meldrum, D.J., 1997. A new small platyrrhine from the Miocene of Colombia and the phyletic position of Callitrichinae. In: Kay, R.F., Madden, R.H., Cifelli, R.L., Flynn, J.J. (Eds.), Vertebrate Paleontology in the Neotropics. Smithsonian Institution Press, Washington, D.C, pp. 435-458.

Kay, R.F., Simons, E.L., 1983. Dental formulae and dental eruption patterns in Parapithecidae (Primates, Anthropoidea). Am. J. Phys. Anthropol. 62, 363-375.

Kay, R.F., Rae, T.C., Koppe, T., Colbert, M.W., 2006. Paranasal pneumatization in the early Miocene platyrrhine Homunculus patagonicus. Am. J. Phys. Anthropol. S41, 112.

Kay, R.F., Fleagle, J.G., Mitchell, T.R.T., Colbert, M.W., Bown, T.M., Powers, D.W., 2008. The anatomy of Dolichocebus gaimanensis, a primitive platyrrhine monkey from Argentina. J. Hum. Evol. 54, 323-382.

Kay, R.F., Perry, J.M.G., Malinzak, M.D., Allen, K.L., Kirk, E.C., Plavcan, J.M., Fleagle, J.G., 2012. The paleobiology of Santacrucian primates. In: Vizcaíno, S, 
Kay, R.F., Bargo, M. (Eds.), Early Miocene Paleobiology in Patagonia: HighLatitude Paleocommunities of the Santa Cruz Formation. Cambridge University Press, Cambridge, pp. 306-330.

Kraglievich, J.L., 1951. Contribuciones al conocimiento de los primates fosiles de la Patagonia. I. Diagnosis previa de un nuevo primat fosil del Oligoceno superior (Colheuhuapiano) de Gaiman, Chubut. Comm. Inst. Nac. Inv. Cien. Nat. II, Cien. Zool. 11, pp. 57-82.

Linnaeus, C., 1758. Systema naturae per regna tria naturae, secundum classes, ordines, genera, species, cum characteribus, differentiis, synonymis, locis. In: Regnum Animale, vol. I. Laurentii Salvii, Stockholm.

Opazo, J.C., Wildman, D.E., Prychitko, T., Johnson, R.M., Goodman, M., 2006 Phylogenetic relationships and divergence times among New World monkeys (Platyrrhini, Primates). Mol. Phylogenet. Evol. 40, 274-280.

Osterholz, M., Walter, L., Roos, C., 2009. Retropositional events consolidate the branching order among New World monkey genera. Mol. Phylogenet. Evol. 50, 507-513.

Perelman, P., Johnson, W.E., Roos, C., Seuánez, H.N., Horvath, J.E., Moreira, M.A.M. Kessing, B., Pontius, J., Roelke, M., Rumpler, Y., Schneider, M.P.C., Silva, A., O'Brien, S.J., Pecon-Slattery, J., 2011. A molecular phylogeny of living primates. PLoS Genet. 3, e1001342.

Perkins, M.E., Fleagle, J.G., Heizler, M.T., Nash, B., Bown, T.M., Tauber, A.A., Dozo, M.T., 2012. Tephrochronology of the Miocene Santa Cruz and Pinturas Formations,Argentina. In: Vizcaíno, S.F., Kay, R.F., Bargo, M.S. (Eds.), Early Miocene Paleobiology in Patagonia: High-Latitude Paleocommunities of the Santa Cruz Formation. Cambridge University Press, Cambridge, UK, pp. 23-40.

Perry, J.M.G., Kay, R.F., Vizcaino, S.F., Bargo, M.S., 2008. First cranial material of a juvenile monkey from the Tertiary of South America: cranial anatomy and dental eruption sequence. J. Vert. Paleontol. 28, 127A.

Perry, J.M.G., Kay, R.F., Vizcaino, S.F., Bargo, M.S., 2010. Tooth root size, chewing muscle leverage, and the biology of Homunculus patagonicus (Primates) from the late early Miocene of Patagonia. Ameghiniana 47, 355-371.

Plavcan, J.M., 1990. Sexual dimorphism in the dentition of extant anthropoid primates. Ph.D. Dissertation, Duke University, Durham, North Carolina.

Rosenberger, A.L., 2011. Evolutionary morphology, platyrrhine evolution, and systematics. Anat. Rec. 294, 1955-1974.

Rosenberger, A.L., Tejedor, M.F., 2013. The misbegotten: long lineages, long branches and the interrelationships of Aotus, Callicebus and the Saki-Uacaris. In: Veiga, L.M., Barnett, A.A., Ferrari, S.F., Norconk, M.A. (Eds.), Evolutionary Biology and Conservation of Titis, Sakis and Uacaris. Cambridge University Press, Cambridge, pp. 13-22.

Rosenberger, A.L., Tejedor, M.F., Cooke, S.B., Pekar, S., 2009. Platyrrhine ecophylogenetics in space and time. In: Garber, P.A., Estrada, A., Bicca-Marques, J.C., Heymann, E.W., Strier, K.B. (Eds.), Comparative Perspectives in the Study of Behavior, Ecology, and Conservation. Springer Science+Business Media, LLC, New York, pp. 69-113. South American Primates.
Ross, C.F., 1995. Allometric and functional influences on primate orbit orientation and the origins of the Anthropoidea. J. Hum. Evol. 29, 210-228.

Rossie, J.B., 2006. Ontogeny and homology of the paranasal sinuses in Platyrrhini (Mammalia: Primates). J. Morphol. 206, 1-40.

Rossie, J.B., Smith, T.D., 2007. Ontogeny of the nasolacrimal duct in primates: functional and phylogenetic implications. J. Anat. 210, 195-208.

Rusconi, C., 1933. Nuevos restos de monos fósiles del Terciario antiguo de la Patagonia. Annales de la Sociedad Científica Argentina 116, 286-289.

Rusconi, C., 1934. Nuevos restos de monos fósiles del Terciario antiguo de la Patagonia. Ann. Soc. Cien. Argentina 96, 286-289.

Rusconi, C., 1935. Las especies de primates del oligoceno de Patagonia (gen. Homunculus). Rev. Argentina Paleontol. Anthropol. 1, 39-68, 71-100, 103-123.

Sanchez-Villagra, M., Williams, B.A., 1998. Levels of homoplasy in the evolution of the mammalian skeleton. J. Mamm. Evol. 5, 113-126.

Scott, W.B., 1928. Mammalia of the Santa Cruz Beds,Volume VI: Palaeontology III, Part IV: Astrapotheria, Part V: Primates. Reports of the Princeton University Expeditions to Patagonia, 1896-1899. Princeton University, E. Schweizerbart'sche Verlagshandlung (E. Nàgele), Stuttgart, pp. 301-351.

Smith, B.H., 1989. Dental development as a measure of life history variation in primates. Evolution 43, 683-688.

Sokal, R.R., Rohlf, F.J., 1981. Biometry, 2nd Edition. W. H. Freeman and Company, New York.

Takai, M., Anaya, F., Shigehara, N., Setoguchi, T., 2000. New fossil materials of the earliest New World monkey, Branisella boliviana, and the problem of platyrrhine origins. Am. J. Phys. Anthropol. 111, 263-281.

Tauber, A., 1991. Homunculus patagonicus Ameghino, 1891 (Primates, Ceboidea), Mioceno Temprano, de la costa Atlantica Austral, prov. de Santa Cruz, Republica Argentina. Acad. Nac. Cien. Córdoba, Argentina 82, 1-32.

Tauber, A., 1994. Estratigrafía y vertebrados fósiles de la Formación Santa Cruz (Mioceno inferior) en la costa atlántica entre las rías del Coyle y Río Gallegos, Provincia de Santa Cruz, República Argentina, Facultad de Ciencias Exactas, Físicas y Naturales. Universidad Nacional de Córdoba, República Argentina, Córdoba, p. 422

Tauber, A.A., 1997. Bioestratigtrafía de la formación Santa Cruz (Mioceno inferior) en el extremo sudeste de la Patagonia. Ameghiniana 34, 413-426.

Tejedor, M.F., 2013. Sistemática, evolución y paleobiogeografía de los primates Platyrrhini. Rev. Mus. La Plata, Sec. Zool. 20, 20-39.

Tejedor, M.F., Rosenberger, A.L., 2008. A neotype for Homunculus patagonicus Ameghino, 1891, and a new interpretation of the taxon. PaleoAnthropology 2008, 67-82.

Tejedor, M.F., Tauber, A.A., Rosenberger, A.L., Swisher III, C.C., Palacios, M.E., 2006. New primate genus from the Miocene of Argentina. Proc. Natl. Acad. Sci. 103, 5437-5441.

Wildman, D.E., Jameson, N.M., Opazo, J.C., Yi, S.V., 2009. A fully resolved genus level phylogeny of neotropical primates (Platyrrhini). Mol. Phylogenet. Evol. 53, 694-702. 